\title{
Simulated annual changes in plant functional types and their responses to climate change on the northern Tibetan Plateau
}

\author{
Lan $\mathrm{Cuo}^{1}$, Yongxin $\mathrm{Zhang}^{2}$, Shilong Piao ${ }^{1}$, and Yanhong $\mathrm{Gao}^{3}$ \\ ${ }^{1}$ Center for Excellence in Tibetan Plateau Earth Sciences, Key Laboratory of Tibetan Environment Changes and \\ Land Surface Processes, Institute of Tibetan Plateau Research, Chinese Academy of Sciences, Beijing, China \\ ${ }^{2}$ Research Applications Laboratory, National Center for Atmospheric Research, Boulder, Colorado, USA \\ ${ }^{3}$ Key Laboratory of Land Surface Process and Climate Change in Cold and Arid Regions, Cold and Arid Regions \\ Environmental and Engineering Research Institute, Chinese Academy of Sciences, Lanzhou, China
}

Correspondence to: Lan Cuo (lancuo@itpcas.ac.cn)

Received: 16 February 2016 - Published in Biogeosciences Discuss.: 18 February 2016

Revised: 27 May 2016 - Accepted: 31 May 2016 - Published: 17 June 2016

\begin{abstract}
Changes in plant functional types (PFTs) have important implications for both climate and water resources. Still, little is known about whether and how PFTs have changed over the past decades on the northern Tibetan Plateau (NTP) where several of the top largest rivers in the world are originated. Also, the relative importance of atmospheric conditions vs. soil physical conditions in affecting PFTs is unknown on the NTP. In this study, we used the improved Lund-Potsdam-Jena Dynamic Global Vegetation Model to investigate PFT changes through examining the changes in foliar projective coverages (FPCs) during 1957-2009 and their responses to changes in root zone soil temperature, soil moisture, air temperature, precipitation and $\mathrm{CO}_{2}$ concentrations. The results show spatially heterogeneous changes in FPCs across the NTP during 1957-2009, with $34 \%$ (13\%) of the region showing increasing (decreasing) trends. Dominant drivers responsible for the observed FPC changes vary with regions and vegetation types, but overall, precipitation is the major factor in determining FPC changes on the NTP with positive impacts. Soil temperature increase exhibits small but negative impacts on FPCs. Different responses of individual FPCs to regionally varying climate change result in spatially heterogeneous patterns of vegetation changes on the NTP. The implication of the study is that fresh water resources in one of the world's largest and most important headwater basins and the onset and intensity of Asian monsoon circulations could be affected because of the changes in FPCs on the NTP.
\end{abstract}

\section{Introduction}

Vegetation dynamics can directly affect water, energy and carbon balances in the coupled land-atmosphere system by responding and providing feedbacks to climate change (Bonan et al., 1992, 2003; Rogers et al., 2013; Ahlstrom et al., 2015; Mengis et al., 2015; Paschalis et al., 2015; Peterman et al., 2015; Sitch et al., 2015; Cuo, 2016). In recent years, dynamic global vegetation models (DGVMs) coupled with atmospheric processes have become valuable tools for examining and understanding the interactive dynamics in carbon, water, and energy exchanges between biosphere and atmosphere. The representation of dynamic vegetation has also become a key component in the earth system models since the last decade (Levis et al., 2004; Sato et al., 2007; Hopcroft and Valdes, 2015). There are many widely used DGVMs that include TRIFFID (Cox, 2001), LPJ (Sitch et al., 2003), BIOME-BGC (Tatarinov and Cienciala, 2006), CENTURY (Smithwick et al., 2009), and OCHIDEE (Ciais et al., 2008), just to name a few. Most of these DGVMs employ the socalled climate envelop approach to control the redistribution of plant, whereas TRIFFID uses the Lotka-Volterra representation of competitive ecological processes for plant redistribution (Fisher et al., 2015).

One common way to describe vegetation in many DGVMs is the adoption of the term plant functional type (PFT) for classifying plants into discrete groups according to their ecological, physiological and phylogenetic traits (Cox, 2001; Sitch et al., 2003). In many of the state-of-the-art hydro- 
logical and land surface models, PFT is both an input for driving the land-atmosphere processes (e.g., Liang et al., 1994, 1996; Wigmosta et al., 1994) and an output of dynamic vegetation simulations (e.g., Sitch et al., 2003). When climate changes, PFTs may migrate or retreat depending on bioclimatic limits and availability of water and light (Pearson et al., 2013). For example, Jiang et al. (2012) examined the Lund-Potsdam-Jena Dynamic Global Vegetation Model (LPJ-DGVM) simulations and showed that temperate trees were more sensitive to climate change than boreal trees and perennial C3 grasses, suggesting that anomalous warming in the northern high latitudes could change the composition of PFTs and cause the northward migration of temperate trees. Changes in the composition of PFTs due to climate change could also modify the foliar projective coverage (FPC, the proportion of ground area that is covered by leaves), an important quantity in determining water, energy, and carbon exchange (Weiss et al., 2014; Meng et al., 2015). Given the fact that evapotranspiration and photosynthesis are closely related to the foliar properties (Swank and Douglass, 1974; Huber and Iroume, 2001; Zhang et al., 2015), some dynamic vegetation models use FPC to represent PFT (e.g., Sitch et al., 2003).

Due to its massive size and high altitude, the Tibetan Plateau (TP) exerts strong influence on regional and global climate through mechanical and thermal-dynamic forcing (Yanai et al., 1992; Wang et al., 2008). The TP is characterized by complex terrain, heterogeneous land surfaces, spatially varying energy and water patterns, diverse ecosystems and bioclimatic zones (Yeh and Gao, 1979; CAS, 2001). The surface conditions of the TP, such as snow cover, soil moisture and vegetation all affect the strength and evolution of the East Asian and South Asian monsoons (Reiter and Gao, 1982; Ye and We, 1998; Zhang et al., 2004; Qiu, 2008). It is also the headwater region of the major rivers in Asia (Cuo et al., 2014). In particular, the northern TP (NTP; 30-40 $\mathrm{N}, 90-105^{\circ} \mathrm{E}$ ) where the Yellow, Yangtze and Mekong Rivers originate, is crucially important in providing water and other ecosystem services to the plateau itself and the downstream regions hosting billions of population. Changes in the composition of different PFTs, and consequently FPCs, could substantially affect surface evapotranspiration, soil water storage and streamflow (Cuo et al., 2009, 2013a, 2015; Weiss et al., 2014; Dahlin et al., 2015), and the partition of net radiation into the sensible and latent heat fluxes, consequently affecting the onset and intensity of south and east Asian monsoon circulations (Wu et al., 2007; Cui et al., 2015). Although there are some studies that connect NDVI (normalized difference vegetation index) and NPP (net primary production) to precipitation, air temperature, and $\mathrm{CO}_{2}$ concentrations on the TP (Zhong et al., 2010; Chen et al., 2012; Piao et al., 2012), very few studies have examined PFT changes and their relationships with climate for the region (Wang et al., 2011).
Besides precipitation, air temperature and $\mathrm{CO}_{2}$ change impacts on the plants, changes in soil temperature and soil moisture could also affect heterotrophic respiration (litter decomposition, soil carbon release, etc.) and vegetation root development. Jin et al. (2013) found that spatial patterns and temporal trends of phenology were parallel with the corresponding soil physical conditions over the $\mathrm{TP}$, and that $1^{\circ} \mathrm{C}$ increase in soil temperature could advance the start of the growing season by 4.6-9.9 days. On the TP where a vast area of seasonally frozen (SFS) and permafrost (PFS) soil exists (Cheng and Jin, 2013), global warming induced frozen soil degradation (Cuo et al., 2015) could potentially affect litter decomposition and plant phenology (Jin et al., 2013).

To date, little is still known about the changes in PFTs or FPC on the NTP in recent decades, much less the mechanisms behind these changes, largely due to the lack of longterm observation data and appropriate research tools. This knowledge gap greatly limits our understanding of TP's vegetation dynamics in response to climate change and the associated implications in the regional and global water, energy and carbon cycles. This study aims to fill this knowledge gap by investigating the changes in PFTs on the NTP in 19572009 and the underlying mechanisms using a dynamic vegetation model, the LPJ-DGVM model. Important atmospheric and soil variables that could significantly affect PFT changes, including precipitation, air temperature, $\mathrm{CO}_{2}$ concentration, soil temperature and soil moisture, are examined and their importance is compared using a dynamic vegetation model.

\section{Methods and data}

\subsection{Study area}

The NTP lies between 1400 and $6100 \mathrm{~m}$ above sea level, with an average elevation of around $3900 \mathrm{~m}$ (Fig. 1). Five large mountains, the Hengduan in the southeast, the Tanggula in the southwest, the Kunlun in the center, the Arjin in the northwest, and the Qilian in the north are located on the NTP. Vegetation on the NTP changes from forest in the southeast to grassland and desert in the northwest, with major vegetation types including temperate evergreen needleleaf forest, summergreen needleleaf and broadleaf forest, temperate shrub/grassland, alpine meadow, alpine steppe, sparsely vegetated bare land and desert. Annual precipitation ranges from $1000 \mathrm{~mm}$ in the southeast to less than $100 \mathrm{~mm}$ in the northwest. Annual air temperature is high in the low elevation (about $15^{\circ} \mathrm{C}$ ) and low in the high elevation (about $-10^{\circ} \mathrm{C}$ ). Details of the spatial patterns of the climate elements and their changes on the NTP over the past five decades can be found in Cuo et al. (2013b). 

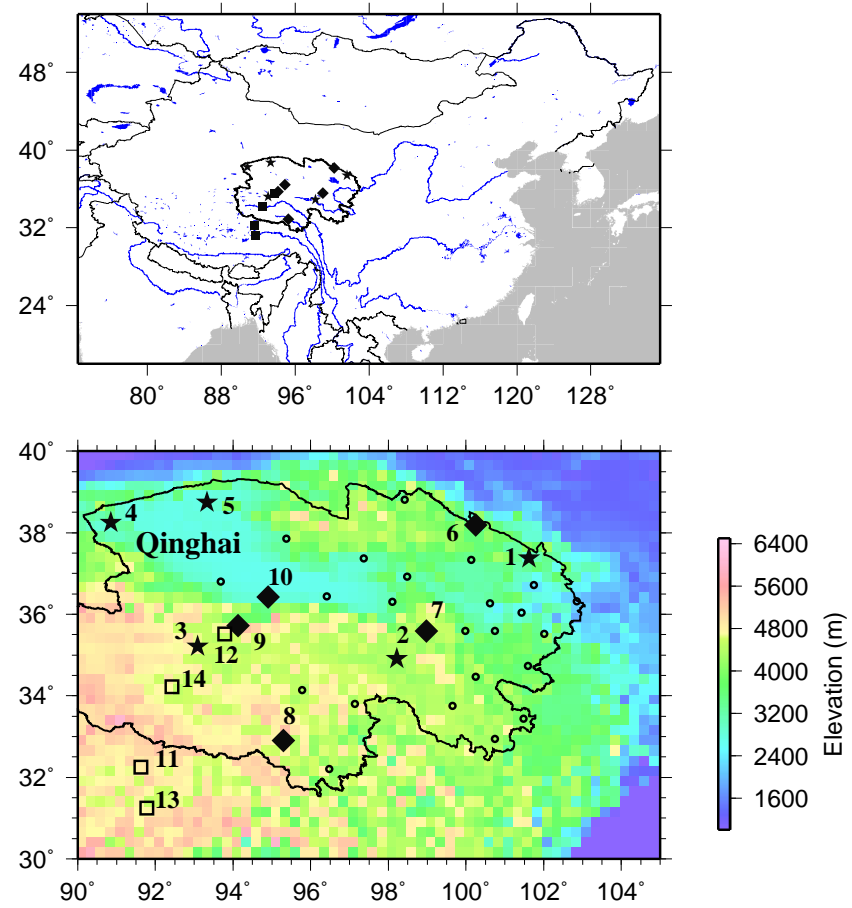

Figure 1. Geographic locations of the study domain and the stations. Black lines outline the boundary of the Qinghai Province. Stars represent the stations whose observations are used to develop the linear regression relationships between daily air temperature and 0-40 cm depth daily soil temperature. Stations denoted as diamonds are for monthly soil temperature evaluation and circles are for annual soil temperature evaluation. The stations are the following: 1 : Mengyuan; 2: Maduo; 3: Wudaoliang; 4: Mangai; 5: Lenghu; 6 Qilian; 7: Xinghai; 8: Zaduo; 9: Xidatan; 10: Germud; 11: Amdo; 12: D66; 13: MS3608; 14: Tuotuohe. Among the stations, Wudaoliang, Xidatan, Amdo, D66, MS3608 and Tuotuohe are permafrost soil sites and all others are seasonally frozen soil sites. Stations 1-10 and circles were used for soil temperature validation while stations 11-14 (empty squares) were used for soil moisture validation.

\subsection{The LPJ model and its parameterizations for the NTP}

We used the LPJ-DGVM model (Sitch et al., 2003; Gerten et al., 2004; LPJ hereafter) to simulate vegetation dynamics, carbon cycle and biogeophysical properties. Vegetation dynamics in LPJ are driven by the processes of competition for water, light and nutrients among plant functional types, with different rates of plant carbon assimilation and allocation, reproduction, and survival. LPJ can simulate photosynthesis, transpiration, soil organic matter and litter dynamics and fire disturbance at daily time step, and resource competition, tissue turnover, population dynamics at annual time step. Plant establishment is determined by bioclimatic limits. Probability of plant mortality is controlled by the interactions among light competition, low growth efficiency, a negative carbon balance, heat stress and bioclimatic limits.
LPJ couples fast hydrological and physiological processes with slower ecosystem processes using daily, monthly, and yearly time scales (Bonan et al., 2003), and has been successfully applied in the simulation of global and regional vegetation dynamics and large scale PFT distributions (Smith et al., 2001; Sitch et al., 2003, 2005, 2008; Gerten et al., 2004; Murray, 2014; Steinkamp and Hickler, 2015).

Six PFTs, temperate needleleaf evergreen trees, temperate broadleaf evergreen trees, temperate broadleaf summergreen trees, perennial alpine meadow grasses, perennial alpine steppe grasses, and perennial temperate summergreen scrub/grassland are compiled and used in the model to represent the major vegetation types on the NTP, based on physiognomic (tree or herbaceous), bioclimatic (temperate, boreal or alpine), phenological (evergreen or summergreen), and photosynthetic $(\mathrm{C} 3$ or $\mathrm{C} 4)$ properties of the plants. The vegetation state of each of the $0.25^{\circ} \times 0.25^{\circ}$ grid cells in LPJ is a mixture of PFTs that can be distinguished by their FPCs. FPC of an individual PFT, ranging from 0 (zero coverage) to 100 (full coverage), is a function of crown area (for trees only), individual PFT density and LAI (leaf area index), and is calculated by the Lambert-Beer law (Sitch et al., 2003). The total FPC of a given space is the sum of the FPCs of all PFTs in that space.

On the NTP, vegetation root system is concentrated in the top $0.4 \mathrm{~m}$ depth where soil undergoes seasonal freezing and thawing cycles. The accuracy of heat and moisture content representation in the top $0.4 \mathrm{~m}$ soil is therefore vital for modelling vegetation dynamics and carbon cycle in this region. In this work, LPJ is configured with two soil layers, $0-0.4 \mathrm{~m}$ (top layer) and $0.4-1.0 \mathrm{~m}$ (bottom layer) below surface, for better accounting for water and energy states of the top soil layer under repeated freezing and thawing cycles on the NTP, while at the same time maintaining its computational efficiency for large scale simulations. Daily temperature of the top soil layer is calculated by linearly regressing it with daily air temperature. The linear relationship is obtained from five stations (stars in Fig. 1) where both soil temperature and air temperature observations are available. These five stations are located in the different parts of the NTP and represent various land cover types (temperate shrub/grassland, alpine meadow, alpine steppe and desert) and soil conditions (SFS and PFS). Depending on the stations, the observation periods are different. Both monthly and annual soil temperature at stations with observation periods greater than 2 years are chosen for the validation of simulated soil temperature. The linear regression equations are developed separately for normal (regular soil moisture) and desert (dry) soils. For normal soil, daily soil (0-0.4 $\mathrm{m}$ depth), and air temperature are obtained from Mengyuan (1983-2009, SFS), Maduo (1980-2009, SFS) and Wudaoliang (2005-2006, PFS; Eq. 1). For desert dry soils where monthly soil moisture is usually around $0.1 \mathrm{~m}^{3} \mathrm{~m}^{-3}$, daily soil, and air temperature are obtained from the Mangai (1988-2009) and Lenghu (19802009) stations (Eq. 2). Note that desert dry soil temperature 
can change quickly due to the lower thermal capacity of dry air $\left(1000 \mathrm{~J} \mathrm{~K}^{-1} \mathrm{~kg}^{-1}\right)$ than that of water $\left(4188 \mathrm{~J} \mathrm{~K}^{-1} \mathrm{~kg}^{-1}\right)$, and the slope for desert dry soil is larger than that for normal soil. Eqs. (1) and (2) are expressed as follows:

$$
\begin{array}{ll}
\mathrm{ST} 1=0.8753 \times \mathrm{AT}+3.1623, \theta>0.1 ; & R^{2}=0.94 \\
\mathrm{ST} 1=1.0873 \times \mathrm{AT}+3.9063, \theta \leq 0.1 ; & R^{2}=0.97
\end{array}
$$

where ST1 is daily soil temperature $\left({ }^{\circ} \mathrm{C}\right)$ in $0-0.4 \mathrm{~m}$ depth, AT is daily air temperature $\left({ }^{\circ} \mathrm{C}\right)$, and $\theta$ is total soil moisture $\left(\mathrm{m}^{3} \mathrm{~m}^{-3}\right) . R^{2}$ is coefficient of determination.

Soil temperature in $0.4-1.0 \mathrm{~m}$ depth is assumed to be a lagged exponential function of the top layer soil temperature. The equations are as follows:

$$
\begin{aligned}
\mathrm{ST} 2 & =\mathrm{ST} 1+(\mathrm{TA}-\mathrm{ST} 1) \times e^{-T s} \\
\mathrm{TA} & =a+b \times\left(N_{\mathrm{d}}-1-T s \times \frac{365}{2 \pi}\right) \\
T s & =\frac{D_{2} \times \frac{3}{4}}{\sqrt{Q_{\mathrm{d}} \times 86400 \times \times^{365} / \pi}} \\
Q_{\mathrm{d}} & =\frac{\mathrm{K}}{C_{\mathrm{s}}},
\end{aligned}
$$

where $\mathrm{K}$ and $C_{s}$ are heat conductivity $\left(\mathrm{W} \mathrm{m}^{-1} \mathrm{~K}^{-1}\right)$ and volumetric heat capacity $\left(\mathrm{J} \mathrm{m}^{-3} \mathrm{~K}^{-1}\right)$, respectively, that are calculated based on the soil mineral and organic content and moisture conditions and are updated at a daily time step; $Q_{\mathrm{d}}$ is heat diffusivity $\left(\mathrm{m}^{2} \mathrm{~s}^{-1}\right) ; D_{2}$ is the depth of the second layer; $N_{\mathrm{d}}$ is the number of days in a year; $a$ and $b$ are the linear regression coefficients of daily air temperature and the numbers of days in a month, respectively, and are updated at a monthly time step. Equation (4) calculates the lag of the thermal change in the second layer soil temperature. The equations employed for the second layer soil temperature are the modified version of the originals used in LPJ.

Total soil moisture in the top soil layer is obtained from the balance between precipitation input, soil evapotranspiration and percolation. Ice and liquid content is calculated based on soil temperature. If soil temperature is below $0^{\circ} \mathrm{C}$, soil liquid content is calculated by using freezing point depression equation. Ice content is the difference between total soil moisture and liquid water content. When soil temperature is greater than $0^{\circ} \mathrm{C}$, soil moisture is liquid and ice content is zero. The equations are the following:

$$
\begin{gathered}
\theta_{l}=\varphi \times\left(\frac{-L_{\mathrm{f}} \times \mathrm{ST} 1}{273.16 \times g \times b_{\mathrm{p}}}\right)^{-\frac{2.0}{n-3}} \\
\text { ST1 }<0 \theta_{i}=\theta-\theta_{l} \quad \mathrm{ST} 1<0
\end{gathered}
$$

where $\theta$ is total soil moisture and subscripts $l$ and $i$ represent liquid and ice, respectively; $\phi$ is soil porosity; $L_{\mathrm{f}}$ is latent heat of fusion $\left(3.337 \times 10^{5} \mathrm{~J} \mathrm{~kg}^{-1}\right) ; g$ is gravitational acceleration $\left(9.81 \mathrm{~m} \mathrm{~s}^{-2}\right) ; b_{\mathrm{p}}$ is the bubbling pressure $(\mathrm{m})$; and $n$ is the exponent in Campbell's equation for hydraulic conductivity. The second layer soil moisture is calculated using the similar equations, and it is the aggregation of liquid and ice content, runoff, percolated moisture from the top layer and to the baseflow. Runoff is generated when liquid soil content is greater than porosity, and percolation is generated when liquid soil content is greater than soil water holding capacity. Runoff and baseflow are produced in both soil layers and are removed from soil moisture. Soil moisture observations are rare on the NTP. Only 1-year observations at four permafrost sites are available during the study period (see Fig. 1) and they are used for soil moisture validation.

The implementation of the aforementioned processes in the LPJ model requires seven additional soil parameters for each of the two soil layers: Campbell's exponent $n$, bubbling pressure $b_{\mathrm{p}}$, bulk densities for organic matter and soil mineral, particle densities for organic matter and soil mineral, and quartz content. Soil porosity $\phi$ is calculated from soil bulk density and soil particle density. These parameters are often used in surface hydrological models for calculating soil hydrological properties (e.g. Liang et al., 1994, 1996; Wigmosta et al., 1994), and are provided for various soil texture types in the LPJ model. These additional parameters together with the original parameters for soil texture, soil percolation rates and water holding capacity constitute the new soil parameter sets. These modifications eliminate the use of fixed heat diffusivity at 0,15 and $100 \%$ water content in the original model version, instead here the diffusivity varies with thermal conductivity and capacity as shown in Eq. (6).

\subsection{Forcing data and observations}

Forcing data used in the LPJ model include monthly air temperature, precipitation, wet days, cloud cover amount and annual $\mathrm{CO}_{2}$ concentrations. Monthly air temperature, precipitation and wet days, all at $0.25^{\circ} \times 0.25^{\circ}$ resolution, were from Cuo et al. (2013b). Cloud cover data came from the Climate Research Unit of the University of East Anglia (Mitchell and Jones, 2005) at $0.5^{\circ} \times 0.5^{\circ}$ resolution and were regridded to $0.25^{\circ} \times 0.25^{\circ}$ resolution assuming uniform distribution of cloud cover within each $0.5^{\circ} \times 0.5^{\circ}$ grid cell. Annual $\mathrm{CO}_{2}$ concentrations were obtained from the Mauna Loa Observatory operated by National Oceanic and Atmospheric Administration (NOAA). Missing $\mathrm{CO}_{2}$ observations for 1957-1958 were filled in by extrapolating the regression between annual $\mathrm{CO}_{2}$ concentrations and the corresponding years. Soil texture data were from the Harmonized World Soil Data v1.0 (FAO, 2008). Elevation data were from the Shuttle Radar Topography Mission (SRTM) and were interpolated to the $0.25^{\circ} \times 0.25^{\circ}$ grids using cubic convolution.

\subsection{Analysis methods}

To spin up, the LPJ model was run iteratively for 1000 years using the 1957-1986 climate data and starting from bare 
Table 1. Calibrated parameters of plant functional types in the Lund-Potsdam-Jena DGVM model.

\begin{tabular}{|c|c|c|c|c|c|c|c|c|c|c|c|}
\hline Plant functional types & $\begin{array}{r}g_{\min } \\
\left(\mathrm{mm} \mathrm{s}^{-1}\right)\end{array}$ & GDDs & $\mathrm{GDD}_{5 \mathrm{~min}}$ & Int & $W_{\mathrm{s}-\mathrm{m}}$ & $\begin{array}{l}\mathrm{RD}_{0} \\
\left({ }^{\circ} \mathrm{C}\right)\end{array}$ & $\begin{array}{r}\mathrm{TLCO}_{2} \\
\left({ }^{\circ} \mathrm{C}\right)\end{array}$ & $\begin{array}{r}\mathrm{TUCO}_{2} \\
\left({ }^{\circ} \mathrm{C}\right)\end{array}$ & $\begin{array}{l}\text { TLP } \\
\left({ }^{\circ} \mathrm{C}\right)\end{array}$ & $\begin{array}{l}\text { TUP } \\
\left({ }^{\circ} \mathrm{C}\right)\end{array}$ & $\mathrm{TL}_{\text {cold }}$ \\
\hline Temperate broadleaf evergreen trees (TBLE) & 1.6 & 400 & 900 & 2.5 & 0.2 & 0.8 & -3 & 30 & 15 & 30 & -0.1 \\
\hline Temperate needleleaf evergreen trees (TNEG) & 1.8 & 300 & 600 & 2.7 & 0.4 & 0.8 & -10 & 15 & 5 & 20 & -15.5 \\
\hline Temperate broadleaf summergreen trees (TBSG) & 1.5 & 300 & 700 & 1.0 & 0.2 & 0.8 & -3 & 20 & 5 & 20 & -10 \\
\hline Perennial alpine meadow (PAMD) & 0.05 & 70 & 60 & 0.1 & 0.2 & 1.0 & -6 & 15 & 0 & 15 & -20 \\
\hline Perennial alpine steppe (PASP) & 0.05 & 10 & 20 & 0.1 & 0.2 & 1.0 & -20 & 5 & -7 & 5 & -25 \\
\hline Temperate summergreen scrub/grassland (TSGS) & 0.4 & 200 & 500 & 0.5 & 0.2 & 1.0 & -10 & 18 & 5 & 18 & -10 \\
\hline
\end{tabular}

Note: $g_{\min }$ : minimum canopy conductance; GDDs: number of growing degree days to attain full leaf cover; $\mathrm{GDD}_{5}$ min $: 5^{\circ} \mathrm{C}$ based minimum degree day; Int: interception storage; $W_{\mathrm{s}-\mathrm{m}}:$ water scalar value at which leaves shed by drought for deciduous plant; $\mathrm{RD}_{0}$ : fraction of roots in the upper soil layer $(0-40 \mathrm{~cm}) ; \mathrm{TLCO}_{2}$ : lower temperature limit for $\mathrm{CO}_{2}$ absorption; $\mathrm{TUCO}_{2}$ : upper temperature limit for $\mathrm{CO}_{2}$ absorption; TLP: lower temperature limit for photosynthesis; TUP: upper temperature limit for photosynthesis; $\mathrm{TL}_{\text {cold: }}$ lower limit of the coldest monthly mean temperature.

Table 2. Scenarios used for examining the FPC sensitivity to climate elements.

\begin{tabular}{lll}
\hline Scenarios & Variables changed & Changed amount \\
\hline S1 & $40 \mathrm{~cm}$-deep daily soil temperature (ST1) & $+1{ }^{\circ} \mathrm{C}$ \\
S2 & $40 \mathrm{~cm}$-deep daily soil moisture (SM1) & $+10 \%$ \\
S3 & Monthly air temperature (AT) & $+1{ }^{\circ} \mathrm{C}$ \\
S4 & Monthly precipitation (PRCP) & $+10 \%$ \\
S5 & Annual CO & $+10 \%$ \\
S6 & AT, PRCP, wet day, $\mathrm{CO}_{2}$ & Trends removed \\
Historical & - & - \\
\hline
\end{tabular}

ground, a common practice among LPJ users. The purpose of this long run is to establish ecosystem equilibrium equivalent to the 1957 conditions. Like earlier studies (e.g., Sitch et al., 2003), we assume that after the 1000-year spin-up, vegetation dynamics, carbon pools, soil thermal and water conditions reach the needed equilibrium.

Given the importance of the top $0.4 \mathrm{~m}$ soils for vegetation root system on the NTP, we validate model simulated soil temperature and moisture in this layer against available observations. Deep layer soil temperature and moisture are also evaluated but will not be shown. Mean, correlation coefficient $(R)$ and root mean square error (RMSE) of monthly and annual mean soil temperature, as well as monthly soil moisture are examined. FPCs are used to represent vegetation states and PFTs. The spatial patterns of the simulated FPCs of dominant PFTs are compared with those of the survey maps compiled by CAS (2001), Zheng et al. (2008) and the MODIS Terra growing season (May-September) averaged annual LAI in 2000-2009. Parameters representing the physiological, phenological and bioclimatic attributes of the six PFTs are adjusted accordingly to obtain a reasonable match between the simulated pattern and the survey maps. Soil parameters used are from Cuo et al. (2013a) and model default settings. The calibrated PFT parameters are listed in Table 1.

Following model evaluation, we examine the changes in total FPCs and FPCs of individual PFTs during 1957-2009 in response to climate change. Climate change is represented by changes in air and $40 \mathrm{~cm}$-deep soil temperatures, $40 \mathrm{~cm}$ deep soil moisture, precipitation and atmospheric $\mathrm{CO}_{2}$ concentration. The Mann-Kendall trend analysis is employed to investigate the FPC trends. Also, the differences between historical simulation and climate trends removed simulation are examined to identify the changes in FPCs during the past five decades.

To investigate the sensitivity of FPCs in each grid cell to changes in soil temperature and moisture, air temperature, precipitation and $\mathrm{CO}_{2}$, six scenarios (S1-S6) are designed (Table 2). In the baseline scenario (S6), the trends in air temperature, precipitation, wet day and $\mathrm{CO}_{2}$ are removed. Soil temperature and moisture respond to atmospheric forcings and they are assumed to have no trends when the trends of atmospheric forcings are removed. The only difference between S1-5 and S6 scenarios is the introduced change in one variable while keeping the other variables unchanged. Cloud cover remains the same for all scenarios. For precipitation, only the amount but not the frequency is changed. These scenarios bear similarity to what has been identified over the NTP in recent decades in general in that S1 plus S2, S3, S4 and S5 represent regional frozen soil degradation, warming, wetting and elevated $\mathrm{CO}_{2}$ trends, respectively, although the rates of changes and spatial patterns differ (Cuo et al., 2013b, 2015). Uniform perturbations are introduced to provide the benchmark for the climate sensitivity comparison across the region and to derive sensitivity spatial pattern. It is expected that the comparisons between the paired S1-S6, S2-S6, S3S6, S4-S6 and S5-S6 scenarios would reveal the responses of FPC to the changes in soil temperature, soil moisture, air temperature, precipitation and $\mathrm{CO}_{2}$, respectively.

Using S1-6 scenarios, we examine elasticity $(E)$, a nonparametric, robust and unbiased estimator (Sankarasubramanian et al., 2001; Elsner et al., 2010) that can better measures how responsive a variable is to a changing condition, in order to quantify the degree of the FPC sensitivity to climate change. Elasticity is calculated as the median of the ratios of percentage changes in annual FPC to the percentage changes in an annual climate variable. Positive (negative) $E$ indicates that FPC increases (decreases) with changing climate variable. Larger $E$ corresponds to higher sensitivity, and when $E$ is zero FPC is not responding to climate change. In the following, we will use $E_{\mathrm{ST} 1}, E_{\mathrm{SM} 1}, E_{\mathrm{AT}}, E_{\mathrm{PRCP}}$ and $E_{\mathrm{CO}_{2}}$ to denote the sensitivity of FPCs to the changes in the top layer 

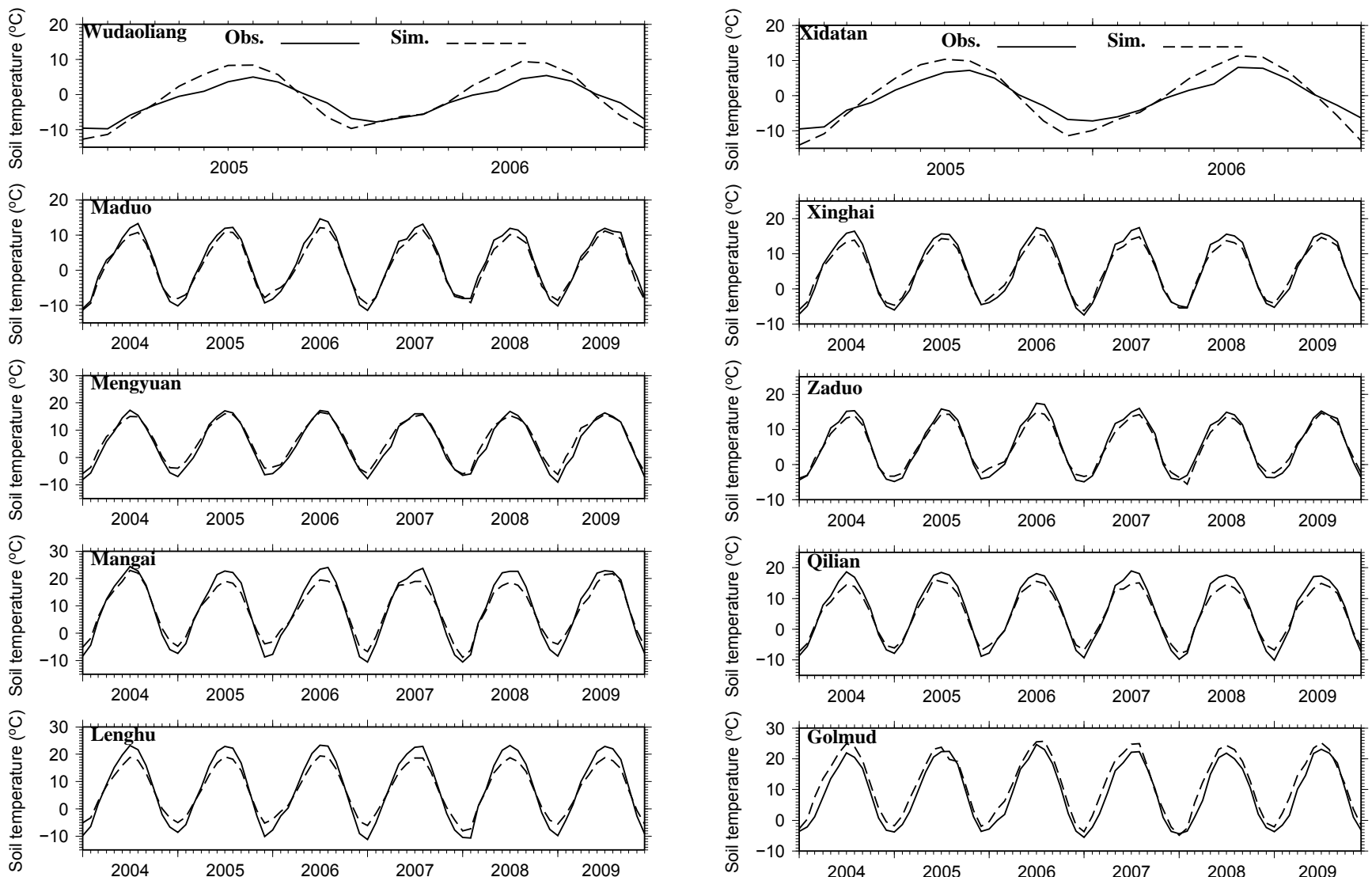

Figure 2. Simulated and observed monthly soil temperature at 5 calibration sites.

soil temperature (ST1) and soil moisture (SM1), air temperature (AT), precipitation (PRCP), and $\mathrm{CO}_{2}$, respectively.

\section{Results}

\subsection{Evaluations of simulated soil temperature, moisture and FPC}

Figure 2 shows the simulated and observed monthly soil temperature in the top $0.4 \mathrm{~m}$ depth at Wudaoliang (PFS), Maduo (SFS), Mengyuan (SFS), Mangai (SFS, dry desert soil) and Lenghu (SFS, dry desert soil). The observations at these sites are also used to derive the linear regression equations that are then applied over the entire domain. At Maduo and Mengyuan, the simulated soil temperature matches the observed rather well in both magnitude and seasonal cycles. At Wudaoliang, the highest station, the simulated magnitude of the seasonal cycle in soil temperature is larger than the observed while the opposite is true at Mangai and Lenghu, two dry desert soil stations. Correlation between the simulations and observations is high $(R \geq 0.96)$ across these five stations and RMSE ranges from $1.40^{\circ} \mathrm{C}$ at Maduo to $3.07^{\circ} \mathrm{C}$ at Lenghu (Table 3).

As an independent check, we also compare the simulated and observed monthly soil temperature of the top soil layer at five other stations whose observations are not used in deriving the linear regression equations (Fig. 3). These five stations are Xidatan (PFS), Xinghai (SFS), Zaduo (SFS), Qilian (SFS), and Golmud (SFS, dry desert soil). All five stations except Xidatan show satisfactory simulations in both magnitude and seasonal cycles when compared to the observations although Qilian displays underestimation in the peaks, while Golmud exhibits slight overestimation in the first half of the years. At Xidatan, a PFS site, the simulated seasonal cycle is larger than the observed, similar to Wudaoling as discussed before. It appears that the derived linear regression relationships may contain some deficiencies at the PFS sites due to the limited observations in the PFS region. RMSE ranges from $1.32^{\circ} \mathrm{C}$ at Zaduo to $3.03{ }^{\circ} \mathrm{C}$ at Golmud and $3.21{ }^{\circ} \mathrm{C}$ at Xidatan (Table 3). Correlation between the simulated and observed monthly soil temperature is higher than 0.97 at these stations (Table 3). For annual soil temperature (Table 3 ), $R$ is generally greater than 0.80 , and RMSE is generally less than $1.5^{\circ} \mathrm{C}$ for all stations except for Nangqian where RMSE is $4.51^{\circ} \mathrm{C}$ and Lenghu where $R$ is 0.53 . These analyses suggest that the modified LPJ model is able to simulate the temporal 
Table 3. Statistics of the observed and simulated monthly and annual mean soil temperature in $0-40 \mathrm{~cm}$ depth. The observations end in 2009 for all stations except for Wudaoliang and Xidatan for which the observations end in 2006. R: correlation coefficient; RMSE: root mean square error.

\begin{tabular}{|c|c|c|c|c|c|c|c|c|}
\hline Stations & Start & Latitude & Longitude & Elevation (m) & Obs. $\left({ }^{\circ} \mathrm{C}\right)$ & Sim. $\left({ }^{\circ} \mathrm{C}\right)$ & $R$ & $\operatorname{RMSE}\left({ }^{\circ} \mathrm{C}\right)$ \\
\hline \multicolumn{9}{|c|}{ Monthly } \\
\hline Wudaoliang & 2005 & 35.217 & 93.083 & 4612.2 & -1.74 & -1.57 & 0.96 & 2.89 \\
\hline Maduo & 2004 & 34.917 & 98.217 & 4272.3 & 2.13 & 0.91 & 0.99 & 1.40 \\
\hline Mengyuan & 2004 & 37.383 & 101.617 & 2938.0 & 5.29 & 6.05 & 0.99 & 1.67 \\
\hline Mangai & 2004 & 38.250 & 90.850 & 2944.8 & 8.81 & 9.70 & 1.00 & 2.68 \\
\hline Lenghu & 2004 & 38.750 & 93.333 & 2770.0 & 7.50 & 6.99 & 1.00 & 3.07 \\
\hline Xinghai & 2004 & 35.583 & 99.983 & 3323.2 & 5.71 & 5.27 & 0.99 & 1.40 \\
\hline Zaduo & 2004 & 32.900 & 95.300 & 4066.4 & 5.67 & 5.31 & 0.99 & 1.32 \\
\hline Qilian & 2004 & 38.183 & 100.250 & 2787.4 & 5.88 & 4.70 & 1.00 & 2.08 \\
\hline Xidatan & 2005 & 35.717 & 94.133 & 4538.0 & -0.45 & -0.70 & 0.98 & 3.21 \\
\hline Golmud & 2004 & 36.417 & 94.900 & 2807.6 & 9.16 & 11.89 & 0.99 & 3.03 \\
\hline \multicolumn{9}{|c|}{ Annual } \\
\hline Mangai & 1989 & 38.250 & 90.850 & 2944.8 & 8.17 & 8.15 & 0.82 & 0.53 \\
\hline Lenghu & 1981 & 38.750 & 93.333 & 2770.0 & 7.56 & 7.82 & 0.53 & 0.70 \\
\hline Delingha & 1982 & 37.367 & 97.367 & 2981.5 & 7.23 & 7.85 & 0.94 & 0.67 \\
\hline Gangcha & 1981 & 37.333 & 100.133 & 3345.0 & 3.59 & 3.89 & 0.90 & 0.38 \\
\hline Mengyuan & 1984 & 37.383 & 101.617 & 2938.0 & 4.69 & 5.63 & 0.93 & 0.97 \\
\hline Germud & 1977 & 36.417 & 94.900 & 2807.6 & 8.53 & 10.48 & 0.68 & 2.08 \\
\hline Qiabuqia & 1983 & 36.267 & 100.617 & 2835.0 & 7.89 & 8.23 & 0.82 & 0.67 \\
\hline Xining & 1962 & 36.717 & 101.750 & 2295.2 & 9.02 & 9.73 & 0.67 & 0.90 \\
\hline Minhe & 1994 & 36.317 & 102.850 & 1813.9 & 11.22 & 11.57 & 0.61 & 0.74 \\
\hline Xinghai & 1993 & 35.583 & 99.983 & 3323.2 & 5.48 & 5.23 & 0.80 & 0.36 \\
\hline Qumalai & 1984 & 34.133 & 95.783 & 4175.0 & 3.05 & 1.46 & 0.90 & 1.63 \\
\hline Maduo & 1981 & 34.917 & 98.217 & 4272.3 & 1.47 & 0.88 & 0.87 & 0.75 \\
\hline Dari & 1981 & 33.750 & 99.650 & 3967.5 & 3.03 & 2.20 & 0.87 & 0.90 \\
\hline Henan & 1982 & 34.733 & 101.600 & 3670.0 & 3.85 & 3.83 & 0.90 & 0.79 \\
\hline Jiuzhi & 1979 & 33.433 & 101.483 & 3628.5 & 4.58 & 3.84 & 0.90 & 0.79 \\
\hline Nangqian & 1994 & 32.200 & 96.483 & 3643.7 & 8.63 & 4.13 & 0.92 & 4.51 \\
\hline
\end{tabular}

evolution of the observed top-layer soil temperature on the NTP with reasonable accuracy.

For monthly soil moisture, the simulations are largely consistent with the observations in terms of magnitude and seasonal cycles as reflected by RMSE and $R$ in the range of $0.08-0.14 \mathrm{~m}^{3} \mathrm{~m}^{-3}$ and $0.71-0.83$, respectively, based on limited observations (Table 4). Slight overestimation of monthly soil moisture is noted at D66 and MS3608 (Table 4).

It is difficult to use the Kappa statistics to evaluate the PFT simulation due to the fact that the vegetation classification systems are different between the observed data sets and the model simulations and any statistical computation would be subject to large uncertainties. Specifically, the land cover classification in Zheng et al. (2008) and CAS (2001) are in polygon format and each polygon contains mixed vegetation classes without any information of the exact location of each individual class within the polygon, which renders it impossible to convert from the polygons that represent the mixed vegetation classes as a whole to the model grid cells that represent the mixed individual vegetation classes. For example, in Zheng et al. (2008), the mixed vegetation class in a polygon includes both temperate semi-arid coniferous forest and steppe in the northeast of the Tibetan Plateau (HIIC1) without showing the exact location of the individual vegetation type; whereas the LPJ simulations are more specific about the location of each vegetation type by using grid cells. We nevertheless presented as many quantitative comparisons as possible.

The comparisons of the simulated LPJ in 2000-2009 with both Zheng et al. (2008) and the CAS (2001) surveyed maps are presented in Fig. 4a, b. The comparisons showed that $69 \%$ of the cells are similar between the LPJ simulation and Zheng et al. (2008) while $42 \%$ of the cells agree with each other between the LPJ simulations and the CAS (2001). The differences between the LPJ simulations Zheng et al. (2008) and CAS (2001) lie mostly in the southeast in that the CAS (2001) map exhibits various subtropical vegetation types and with temperate scrub/grassland-dominated regions in the southeast, while the LPJ simulations and Zheng et al. (2008) display temperate needleleaf evergreen trees. On 
Table 4. Statistics of the first layer $(0-40 \mathrm{~cm})$ monthly soil moisture. The observation period is August 1997-September 1998.

\begin{tabular}{lrrrrrrr}
\hline Stations & Latitude & Longitude & $\begin{array}{r}\text { Elev. } \\
(\mathrm{m})\end{array}$ & $\begin{array}{r}\text { Mean Obs. } \\
\left(\mathrm{m}^{3} \mathrm{~m}^{-3}\right)\end{array}$ & $\begin{array}{r}\text { Mean Sim. } \\
\left(\mathrm{m}^{3} \mathrm{~m}^{-3}\right)\end{array}$ & $R$ & $\begin{array}{r}\text { RMSE } \\
\left(\mathrm{m}^{3} \mathrm{~m}^{-3}\right)\end{array}$ \\
\hline Amdo & 32.25 & 91.63 & 4700 & 0.14 & 0.15 & 0.76 & 0.10 \\
D66 & 35.52 & 93.78 & 4600 & 0.08 & 0.13 & 0.83 & 0.10 \\
MS3608 & 31.24 & 91.78 & 4610 & 0.16 & 0.20 & 0.80 & 0.14 \\
Tuotuohe & 34.22 & 92.43 & 4353 & 0.12 & 0.13 & 0.71 & 0.08 \\
\hline
\end{tabular}

the other hand, the LPJ simulation and the CAS (2001) map show more similarity in the northeast where alpine meadow and temperate scrub/grassland are widely distributed than between the LPJ simulations and Zheng et al. (2008).

The annual MODIS Terra LAI obtained from MaySeptember (growing season) MODIS Terra LAI was compared with the LPJ simulated FPC for 2000-2009 (Fig. 4c, d). The spatial patterns of the MODIS LAI and the LPJ simulated FPC show similarities to some extent. For example, in the northwest, where LAI is low, FPC is also small. Major differences exist mainly in the southwest where FPC is greater than $90 \%$ but LAI is less than 0.3 , most likely because of the small leaf area coverage but high density of individual PFTs in the steppe and meadow-dominated regions.

The spatial patterns of the LPJ simulated PFT (Fig. 4a) and the MODIS LAI (Fig. 4c) match quite well in general, in that barren/sparse grassland corresponds with LAI less than 0.2 ; alpine steppe corresponds with LAI in 0.2-03; alpine meadow corresponds with LAI in $0.3-0.5$; and temperate forest and scrub/grassland corresponds with LAI greater than 0.8. These analyses indicate that the LPJ simulations, though not perfect, are reasonable. Overall, temperate needleleaf evergreen forest (TNEG hereafter), perennial alpine meadow (PAMD), perennial alpine steppe (PASP), perennial temperate summergreen shrub/grassland (TSGS), and barren/sparse grassland prevail over the NTP (Fig. 4a).

\subsection{Changes in FPCs and climatic factors}

The Mann-Kendall trends of annual total FPC (the sum of FPCs of all PFTs in one grid cell), top layer annual soil moisture and temperature, annual precipitation and air temperature during 1957-2009 are presented in Fig. 5. For FPC, $34 \%$ $(13 \%)$ of the region shows increasing (decreasing) trends. Decreasing FPCs are found mostly in the northwest (barren/sparse grassland) and east (TSGS) of the NTP, while increasing FPCs are located mainly in the northeast and southwest where alpine meadow, steppe and temperate summergreen shrub/grassland dominate. The variation in the change was also found by Zhong et al. (2010) who reported that $50 \%$ of the entire TP had increased NDVI with $30 \%$ of the region had decreased NDVI during 1998-2006, with most of the increases occurring in the alpine steppe and alpine meadow in the TP. Further, the LPJ simulated Mann-Kendall trends of NPP (not shown) exhibit similar spatial patterns to those in

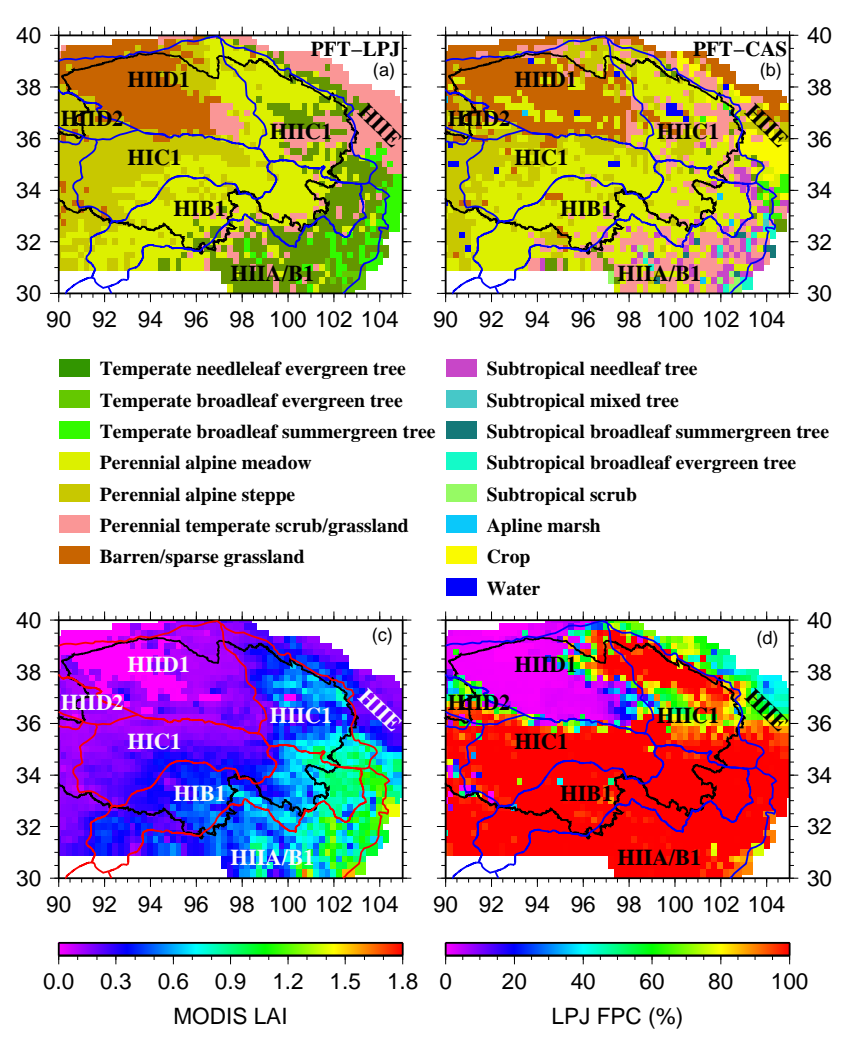

Figure 4. Eco-geographic regions from Zheng et al. (2008) (blue lines in $\mathbf{a}, \mathbf{b}, \mathbf{d}$ and red lines in $\mathbf{c}$ ) and the LPJ simulated dominant plant functional types represented by foliar projective covers (FPCs) under full leaf during 1957-2009 (a); Zheng et al. (2008) and CAS (2001) surveyed maps (b); MODIS Terra LAI and Zheng et al. (2008) maps (c); and LPJ simulated FPC and Zheng et al. (2008) maps (d). The eco-geographic regions are the following: HIIC1: plateau temperate semi-arid high mountain and basin coniferous forest and steppe region; HIID1: plateau temperate arid desert region; HIID2: plateau temperate high mountain arid desert region; HIC1: plateau sub-cold semi-arid alpine meadow-steppe region; HIB1: plateau sub-cold sub-humid alpine shrub-meadow region; HIIA/B1: plateau temperate humid/sub-humid high mountain and deep valley coniferous forest region; and HIIE: temperate shrub grass-desert region. Black line outlines the Qinghai Province.

Piao et al. (2012) in that the increase trends prevail in the northeast and the south of the NTP and more widely spread than those of the total FPC. These similarities further demon- 

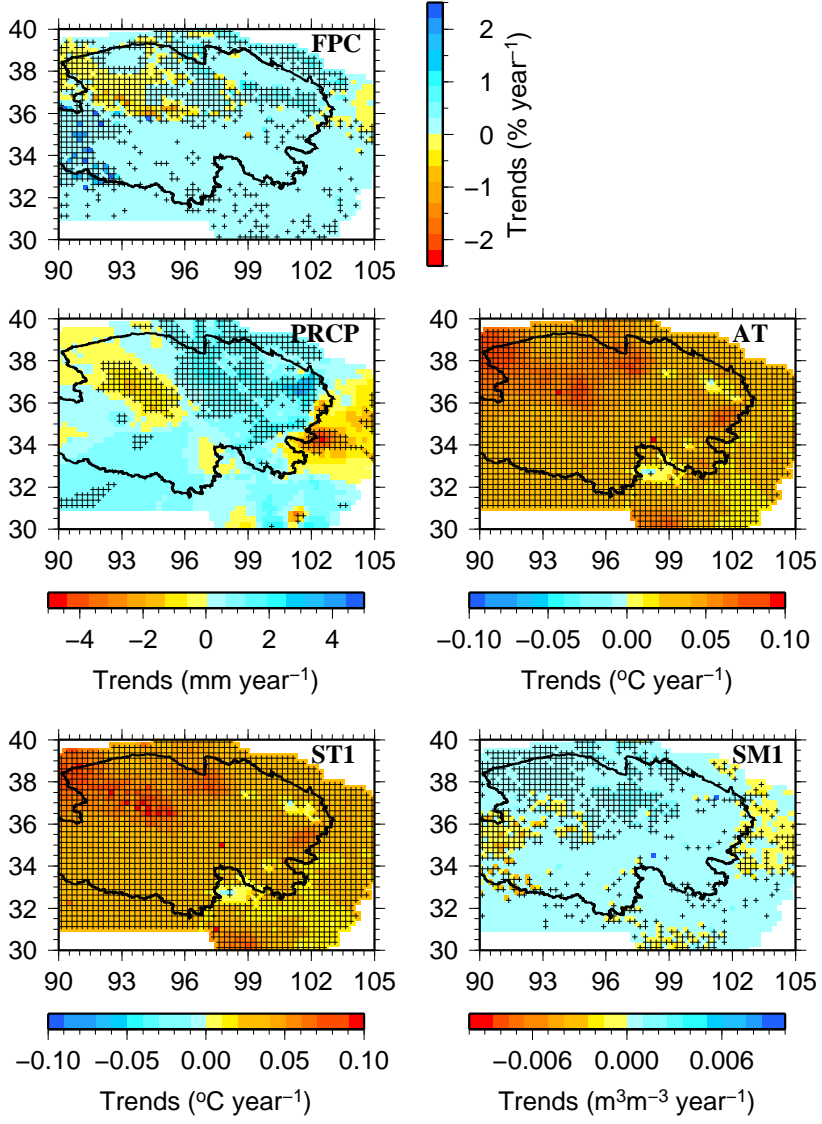

Figure 5. Mann-Kendall trends of simulated annual total FPC, 0-40 cm depth soil temperature (ST1), 0-40 cm depth soil moisture (SM1), and observed precipitation (PRCP) and air temperature (AT). Symbol “+" represents statistically significant trends at $95 \%$ confidence level.

strate LPJ's ability in satisfactorily simulating FPCs and their changes.

Precipitation increases significantly in the northeast but decreases in the northwest and east of the NTP over the last five decades (Fig. 5). This change pattern in precipitation largely resembles that of total FPC. Annual changes in the top layer soil moisture also show a similar spatial pattern to that of precipitation although the trends in soil moisture are generally small over $79 \%$ of the region. Both the top layer soil temperature and air temperature exhibit warming trends over the entire NTP, with significant trends in the northwest and the east (Fig. 5). Hence, compared to increasing temperatures, changes in precipitation appear to play a more important role in determining the spatial patterns of FPC changes on the NTP. However, over the northwestern and eastern NTP, the decreasing FPC trends may also be influenced by the warming in addition to the decreases in precipitation.

The Mann-Kendall trends of FPCs of the four dominant vegetation types, TNEG, PAMD, PASP and TSGS, are
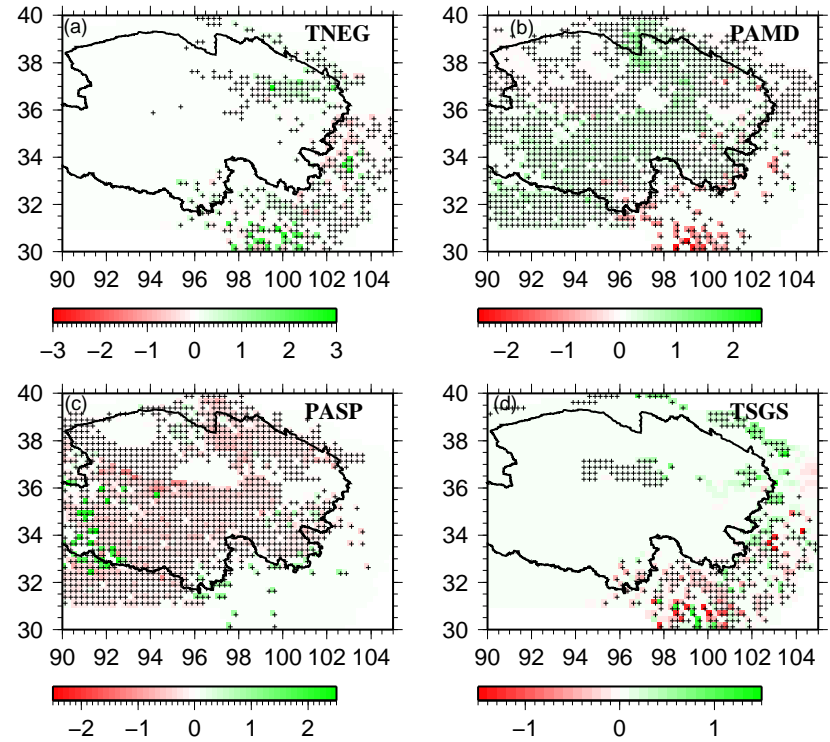

Figure 6. Simulated Mann-Kendall trends of individual FPCs in 1957-2009. TNEG: Temperate needleleaf evergreen, PAMD: perennial alpine meadow, PASP: perennial alpine steppe, TSGS: temperate summer green scrub/grassland. Symbol "+" represents statistically significant trends at $95 \%$ confidence level.

shown in Fig. 6. TNEG displays patches of increasing FPCs (13\% of the entire area) in the northeast and southeast of the NTP. PAMD (PASP) exhibits predominantly increasing (decreasing) FPCs within the Qinghai Province, accounting for $45 \%(44 \%)$ of the entire area. FPCs of TSGS increase (13\% of the entire area) mainly in the northeast and decrease (9\% of the entire area) mainly in the southeast of the NTP. Overall, it appears that PAMD has invaded into the domain of PASP over the past 50 years.

To further investigate possible vegetation migration caused by climate change over the NTP during 1957-2009, we examine FPC differences between simulations with and without the historical trends in climate variables retained (i.e., Historical - S6 in Table 2). The results presented in Fig. 7 suggest that by climate change alone, total FPC (Fig. 7a) would increase by about $20-30 \%$ in the northeast and southwest of the NTP but decrease by less than $30 \%$ in some sporadically vegetated locales. FPC decreases in the northwestern NTP where sparse grassland meets bare land implies an encroachment of desertification in that region and is especially worrisome. Climate change causes increases in FPC of TNEG by about 30-60\% in most of the eastern NTP (Fig. 7b), and it decreases FPC of PAMD (30-60\%) in the eastern NTP but increases FPC of PAMD $(<30 \%)$ in the higher interior of the Qinghai Province, resulting in westward migration of PAMD (Fig. 7c). On the other hand, as a result of climate change, FPC of PASP decreases in most of the Qinghai Province but increases (by $>30 \%$ ) in the westernmost part of the NTP (Fig. 7d). TSGS increases 

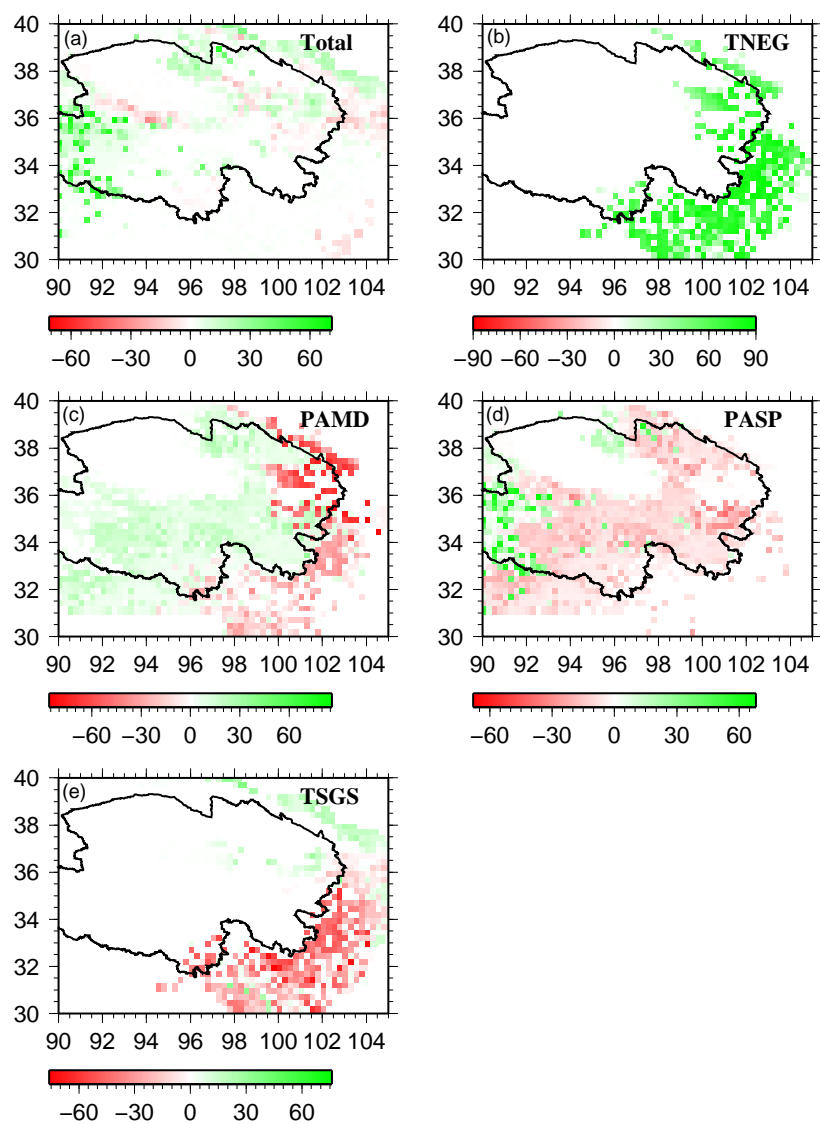

Figure 7. Differences (\%) in total FPC and individual FPCs between historical climate simulation and trend-removed climate simulation.

by less than $30 \%$ in the northeastern NTP but decreases by more than $30 \%$ in the southeast (Fig. 7e) due to climate change. The spatial patterns of the FPC changes due to climate change correspond well with those of the FPC trends (Figs. 5, 6), indicating the dominant role of climate change in governing vegetation changes and dynamics on the NTP.

\subsection{Sensitivity of total FPC to changes in climatic factors}

$E_{\mathrm{PRCP}}$ is positive in $40 \%$ of the area and is often larger than 3 , meaning that $10 \%$ precipitation increase could lead to more than 3-fold increase in total FPC in warm and dry places where alpine meadow, barren/sparse grassland, and temperate summergreen scrub/grassland grow (Fig. 8a). Isolated negative $E_{\mathrm{PRCP}}$ are located mostly in the high elevation of the southern NTP. About $15 \%$ (35\%) of the NTP shows positive (negative) $E_{\mathrm{AT}}$. Negative $E_{\mathrm{AT}}(-3$ to -0.5 ) is mostly found in the northern NTP (Fig. 8b), indicating that $1{ }^{\circ} \mathrm{C}$ warming could lead to $0.5-3$-fold decrease in total FPC. In the far southwest $\left(32-36^{\circ} \mathrm{N}\right.$ and $\left.90-93^{\circ} \mathrm{E}\right)$ where mean annual air temperature is about $-10^{\circ} \mathrm{C}$ and where permafrost soil prevails, $E_{\mathrm{AT}}$ is significantly positive, implying
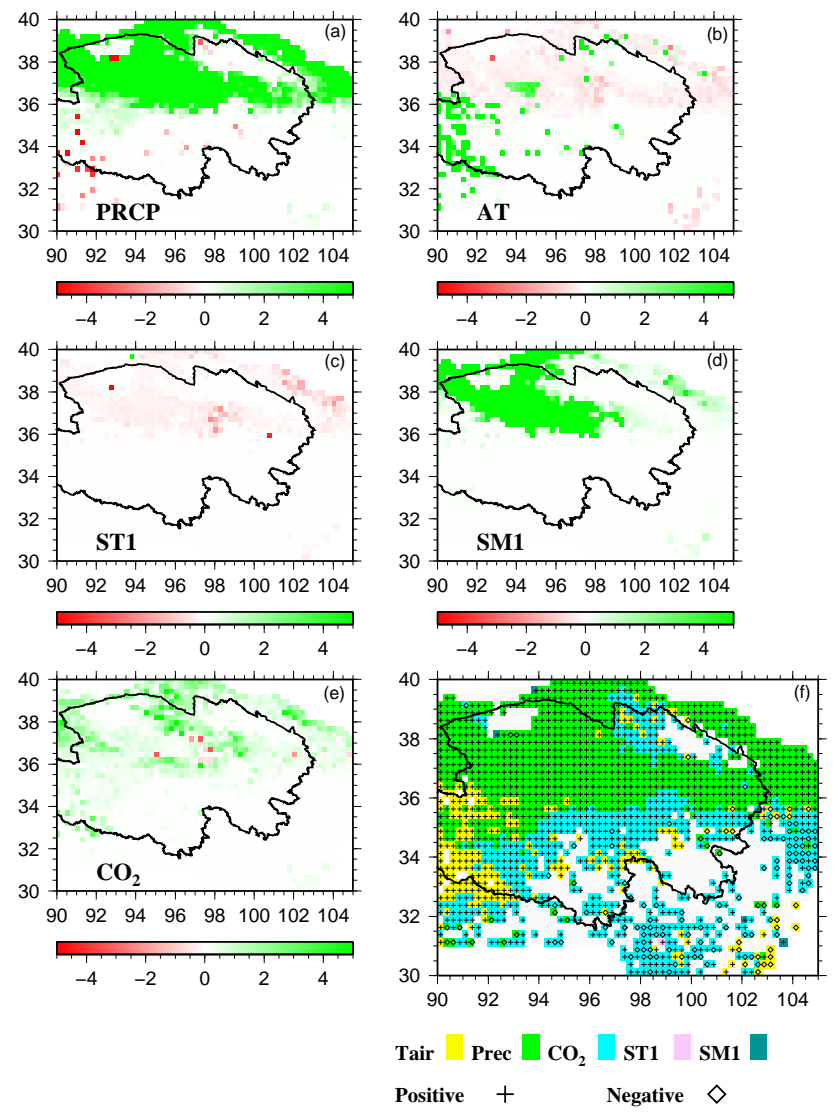

Figure 8. Elasticity of total FPC with precipitation increased by $10 \%$ (a), air temperature increased by $1^{\circ} \mathrm{C}(\mathbf{b})$, soil temperature increased by $1^{\circ} \mathrm{C}(\mathbf{c})$, soil moisture increased by $10 \%$ (d), $\mathrm{CO}_{2}$ increased by $10 \%$ (e), and dominant elasticity related with changes in precipitation, air temperature, soil temperature, soil moisture and $\mathrm{CO}_{2}$ (e). In (f), + (plus) and $\diamond$ (diamond) represent positive and negative elasticity, respectively.

that warming could dramatically increase FPC more than 4fold.

$1{ }^{\circ} \mathrm{C}$ increase in soil temperature could decrease FPC up to 4-fold in the northern NTP (Fig. 8c); however, in the meantime, $10 \%$ increase in soil moisture would result in up to a 5fold increase in FPC in roughly the same area (Fig. 8d), suggesting that FPC is highly sensitive to soil moisture changes especially in the climatologically dry northwest. In the south NTP, FPC seems insensitive to changes in either soil temperature or soil moisture (Fig. 8c, d).

Positive $E_{\mathrm{CO}_{2}}$ is slightly more widely distributed than $E_{\mathrm{PRCP}}$ and $E_{\mathrm{SM} 1}$ but $E_{\mathrm{CO}_{2}}$ is in general much smaller in magnitude than $E_{\mathrm{PRCP}}$ and $E_{\mathrm{SM} 1}$ (Fig. 8e). About $62 \%$ (4\%) of the cells show positive (negative) $E_{\mathrm{CO}_{2}}$. The spatial patterns of elasticity show that foliage growth in heat or water limited NTP is very sensitive to environmental changes. Figure $8 \mathrm{f}$ depicts the dominant drivers that affect total FPC in each grid cell. Precipitation increase (light green in Fig. 8f) 
Table 5. Numbers of the cells that display positive $(+)$, negative (-) and non or negligible $(n)$ elasticity for the four major plant functional types with precipitation increased by $10 \%$ (Prcp $10 \%$ ), air temperature increased by $1{ }^{\circ} \mathrm{C}(\mathrm{AT}+1)$, top layer soil temperature increased by $1{ }^{\circ} \mathrm{C}(\mathrm{ST}+1)$, top layer soil moisture increased by $10 \%$ (SM $10 \%$ ), and $\mathrm{CO}_{2}$ concentrations increased by $10 \%\left(\mathrm{CO}_{2} 10 \%\right)$. There are 2052 grid cells in total. TNEG: temperate needleleaf evergreen trees, PAMD: perennial alpine meadow, PASP: perennial alpine steppe, TSGS: temperate summergreen scrub/grassland.

\begin{tabular}{lcrrrr}
\hline Scenarios & Cell signs & TNEG & PAMD & PASP & TSGS \\
\hline \multirow{3}{*}{ Prcp 10\% } & + & 368 & 1064 & 530 & 184 \\
& - & 68 & 112 & 509 & 317 \\
& $\mathrm{n}$ & 1616 & 876 & 1013 & 1551 \\
$\mathrm{AT}+1$ & + & 216 & 761 & 132 & 348 \\
& - & 364 & 711 & 1226 & 237 \\
& $n$ & 1472 & 580 & 694 & 1467 \\
$\mathrm{ST}+1$ & + & 19 & 39 & 2 & 254 \\
& - & 327 & 522 & 421 & 165 \\
& $n$ & 1706 & 1491 & 1629 & 1633 \\
$\mathrm{SM} \mathrm{10 \%}$ & + & 701 & 1012 & 418 & 142 \\
& - & 36 & 72 & 492 & 340 \\
& $n$ & 1315 & 968 & 1142 & 1570 \\
$\mathrm{CO}_{2} 10 \%$ & + & 280 & 1302 & 590 & 185 \\
& - & 99 & 64 & 557 & 336 \\
& $n$ & 1673 & 686 & 905 & 1531 \\
\hline
\end{tabular}

displays major influence on total FPC in the north with primarily positive effects (crosses in Fig. 8f). Air temperature increase is less important than precipitation increase and could exert either positive (crosses in Fig. 8f) or negative (diamonds in Fig. 8f) effects on total FPC depending on the locations. Generally speaking, positive (negative) effects due to air temperature increase tend to be clustered in the relatively cold and wet southwest (dry northwest and warm southeast). $\mathrm{CO}_{2}$ change impacts are mainly seen over the south and some patchy areas of the north with mixed positive and negative effects. Compared to the other environmental variables, ST1 and SM1 do not emerge as the dominant factors for FPC changes, indicating that frozen soil degradation related to soil temperature and moisture changes is not as important as changes in precipitation, air temperature and $\mathrm{CO}_{2}$ for FPC.

\subsection{Sensitivity of the FPC of individual PFTs to changes in climatic factors}

The FPC of TNEG increases by 1.6-fold on average in response to $10 \%$ precipitation increase in the eastern NTP (about $17 \%$ of the entire area, Fig. 9a, Table 5). The FPC of PAMD increases in $51 \%$ of the area by more than 1.2fold in the east, north and south of the Qinghai Province, but decreases in $5 \%$ of the entire area by about 1-fold in the bare and sparse grassland and by about 5-fold in several cells in the eastern and southern NTP as precipitation increases by $10 \%$. The FPC of PASP decreases in the northeast and
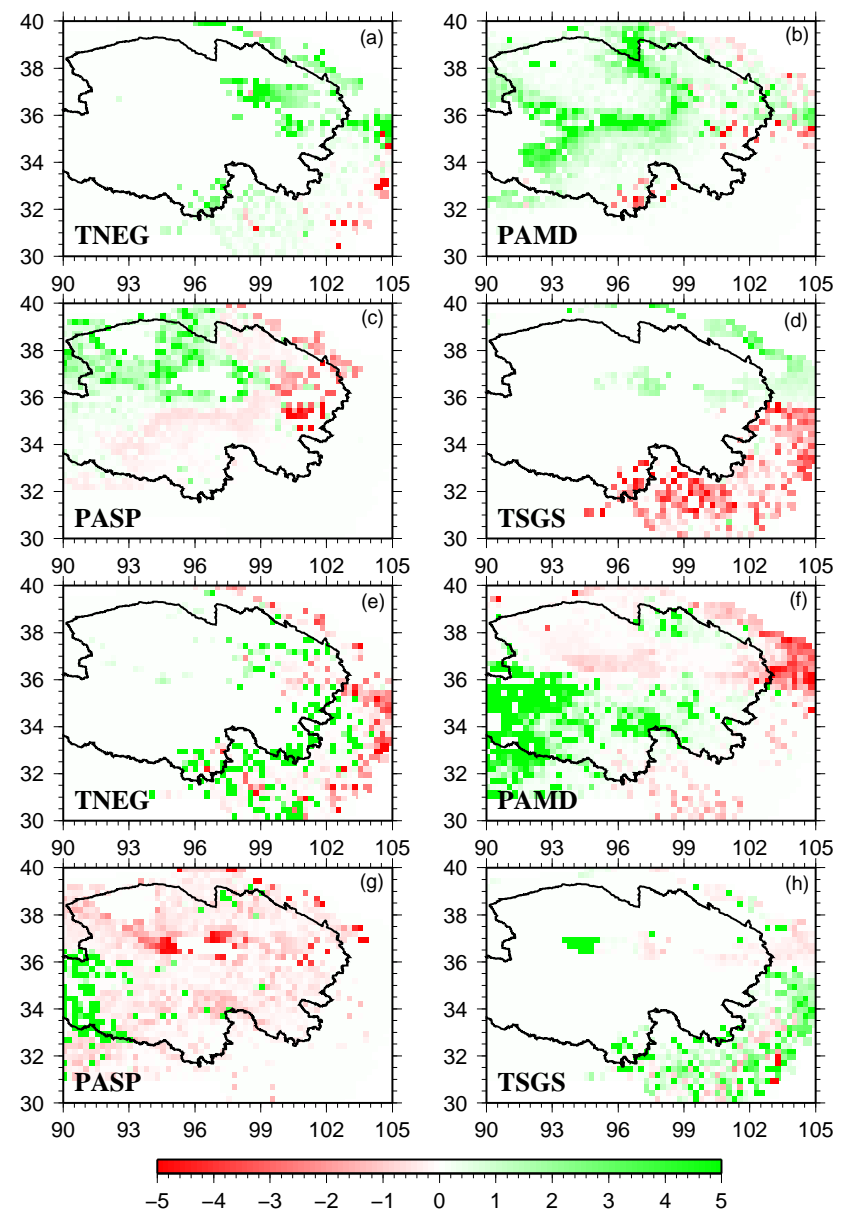

Figure 9. Elasticity of individual FPCs with precipitation increased by $10 \%$ (a-d) and air temperature increased by $1{ }^{\circ} \mathrm{C}(\mathbf{e}-\mathbf{h})$. TNEG: temperate needleleaf evergreen; PAMD: perennial alpine meadow; PASP: perennial alpine steppe; TSGS: temperate summer green scrub/grassland.

south of the Qinghai Province (24\% of the region, Table 5) by about 1 -fold, but increases in the northwest desert region of the Qinghai Province by 1- to 3-fold (Fig. 9c). More cells showing positive $E_{\mathrm{PRCP}}$ for PAMD than for PASP indicates that precipitation increase would benefit PAMD more than PASP. It appears that as precipitation increases, PAMD takes over PASP in many cells while PASP encroaches the desert area. The FPC of TSGS decreases in the southeast by about 1.8 -fold but increases by 1.1 -fold in the northeast of the NTP with $10 \%$ precipitation increases (Fig. 9d). The southeast NTP is not water limited and hence increasing precipitation has negative impacts in general.

Large $E_{\mathrm{AT}}$ for TNEG is found primarily in the eastern NTP, with positive (16\% of the cells) and negative (17\% of the cells) $E_{\mathrm{AT}}$ occurring side by side (Fig. 9e). With $1^{\circ} \mathrm{C}$ air temperature increase, PAMD shows positive $E_{\mathrm{AT}}$ (about 5) in the southwest where energy is limited, but negative $E_{\mathrm{AT}}$ ( -1 to -5 ) in the north, east and southeast (Fig. 9f). For PASP, 

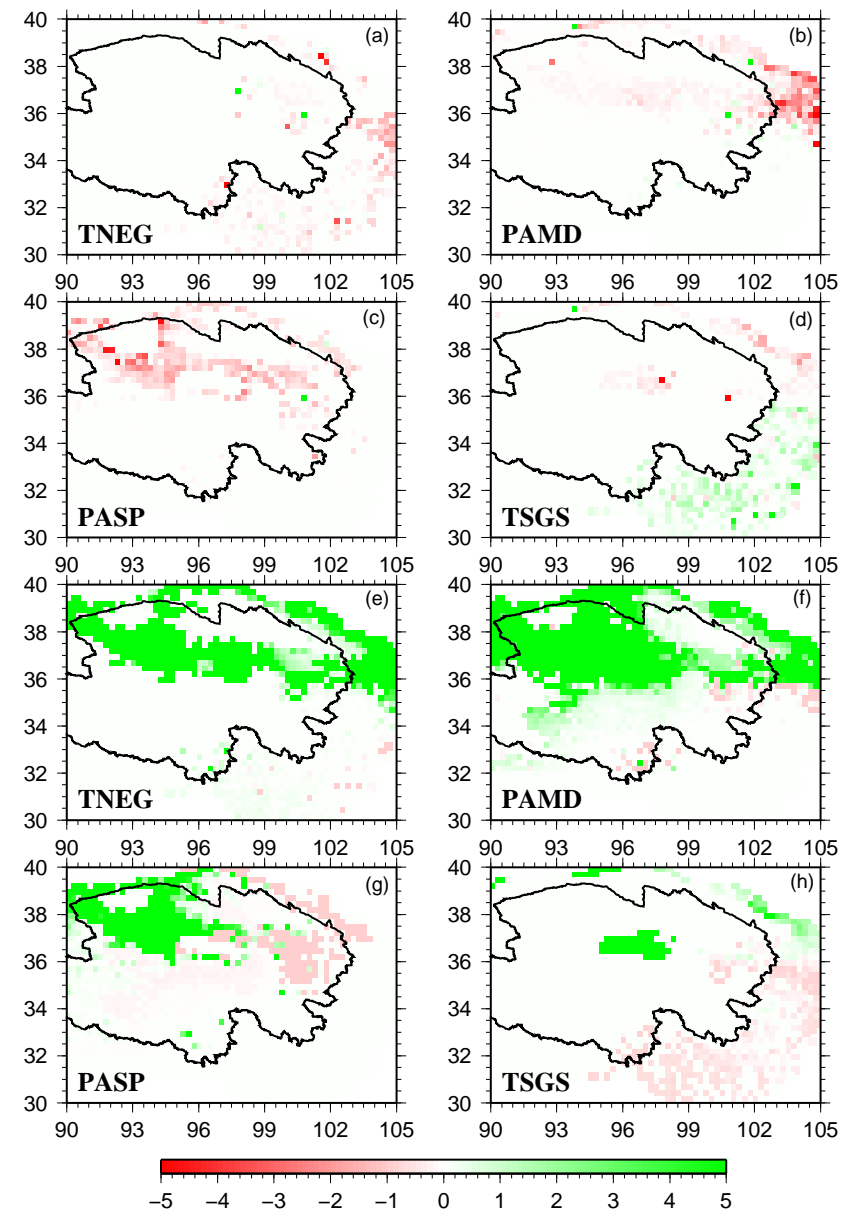

Figure 10. Elasticity of individual FPCs with $+1{ }^{\circ} \mathrm{C}$ soil temperature increase (a-d) and $10 \%$ soil moisture increase (e-h).

large and positive $E_{\mathrm{AT}}$ is found predominantly over the westernmost tip of the NTP, whereas nearly the entire Qinghai Province (59\% of the region) corresponds to negative $E_{\mathrm{AT}}$ (Fig. 9g, Table 5), indicating that PASP would decline in general as air temperature increases. TSGS shows mixed positive and negative $E_{\mathrm{AT}}$ primarily in the northeast and southeast, respectively (Fig. 9h). For TSGS and TNEG, $E_{\mathrm{AT}}$ is close to zero over nearly the entire Qinghai Province (Fig. 9, Table 5), because of the bioclimatic restriction of their establishment.

Although soil temperature and moisture changes do not contribute significantly to total FPC changes (Fig. 8f), they do affect individual PFTs in a nearly opposite way which may have given rise to some cancellation in FPC changes. For example, with the exception of TNEG, negative $E_{\mathrm{ST} 1}$ over the north and positive $E_{\mathrm{ST} 1}$ over the southeast for PAMD, PASP and TSGS correspond respectively to positive and negative $E_{\mathrm{SM} 1}$ in the same areas (Fig. 10), although $E_{\mathrm{SM} 1}$ is generally larger in magnitude than $E_{\mathrm{ST} 1}$. For TNEG, slightly negative $E_{\mathrm{ST} 1}$ is located over the east but highly positive $E_{\mathrm{SM} 1}$ is seen over the north (Fig. 10a, e). Compared to $E_{\mathrm{AT}}, E_{\mathrm{ST} 1}$ is smaller and varies less spatially (Fig. 10a- d). The majority cells (72-83\%) display zero $E_{\mathrm{ST} 1}$ for all four PFTs (Table 5), indicating that soil temperature is not a sensitive element for foliage growth. However, soil moisture increase could reduce the coverage of desert, evidenced by the increase of FPCs of TNEG, PAMD and PASP in the northwest where desert vegetation dominates.

$E_{\mathrm{CO}_{2}}$ (Fig. 11a-d) exhibits a similar pattern to that of $E_{\text {PRCP }}$ for all four PFTs (Fig. 9a-d). The numbers of the grid cells with positive, negative and negligible values of $E_{\mathrm{CO}_{2}}$ and $E_{\mathrm{PRCP}}$ are also similar for each PFT (Table 5). This similarity between $E_{\mathrm{CO}_{2}}$ and $E_{\mathrm{PRCP}}$ suggests a strong coupling between photosynthesis and water availability on the NTP.

\section{Discussions}

Our analyses suggest that total FPC changes on the NTP are driven by different mechanisms over different regions. For example, the increases of total FPC in the southwest during 1957-2009 identified in Figs. 5 and 7a are due to warming induced increases in alpine meadow and steppe. Over the northeast of the NTP, changes in total FPC are determined by the balance between precipitation, soil moisture and $\mathrm{CO}_{2}$ increase induced expansion (contraction) of temperate needleleaf evergreen forest, perennial alpine meadow, perennial temperate summergreen scrub/grassland (perennial alpine steppe) and warming induced decreases in all FPCs. Decreases of total FPC in the northwestern NTP are related to the negative effects of warming and drying (Fig. 5) on the growth of alpine meadow and steppe which apparently overwhelms the positive effects of $\mathrm{CO}_{2}$ increase. In the southeast, changes in total FPC are generally small, likely because of the thriving TNEG growth induced by the increase of temperature, precipitation and $\mathrm{CO}_{2}$ cancelled by the decline of PAMD because of warming, and decreased TSGS due to wetting and $\mathrm{CO}_{2}$ increase. Similarly, in the central region, PAMD and PASP respond oppositely to the changes in precipitation, air temperature, soil moisture and $\mathrm{CO}_{2}$, and as a result total FPC shows little change.

Different regions of the NTP are characterized by distinctive climatic features, and hence vegetation growth in those regions is limited by varying climatic factors. For example, warming and wetting in the southwest of the NTP make it more suitable for alpine meadow and steppe to grow. On the other hand, the northwestern NTP has very limited annual precipitation $(<100 \mathrm{~mm})$, and the warming could make it even drier (as observed during the recent decades, see Fig. 5), posing an increasing challenge for plant growth. As climate changes, bioclimatic zones will change accordingly.

Another noteworthy finding is that as soil temperature increases across the region, there are more grid cells showing decreasing (14\%) than increasing (5\%) top layer annual soil moisture (Fig. 5). The rise in soil temperature on the NTP increases liquid soil moisture during cold months because of the increased soil thawing but decreases liquid soil moisture 

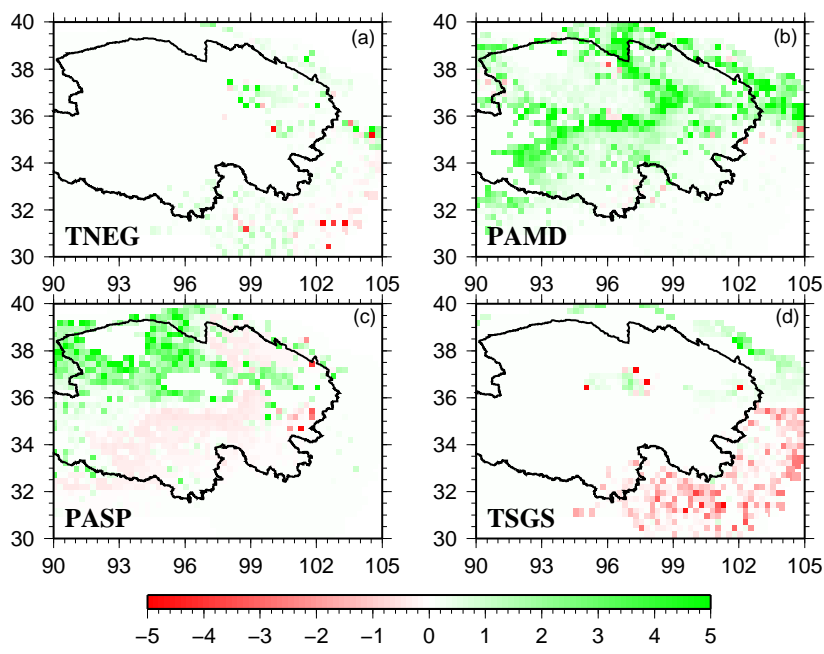

Figure 11. Elasticity of individual FPCs with $10 \% \mathrm{CO}_{2}$ increase.

Table 6. The responses of the FPCs of individual PFTs to $\mathrm{CO}_{2}$ increase.

\begin{tabular}{lll}
\hline & $\begin{array}{l}\text { Cells of positive } \\
\text { response }\end{array}$ & $\begin{array}{l}\text { Cells of negative } \\
\text { response }\end{array}$ \\
\hline FPC of TNEG & 367 & 140 \\
FPC of PAMD & 1567 & 100 \\
FPC of PASP & 671 & 658 \\
FPC of TSGS & 341 & 374 \\
Total FPC & 1596 & 152 \\
\hline
\end{tabular}

during warm months because of the enhanced soil evaporation in shallow soil layers (Cuo et al., 2015). Clearly, the decrease in top layer soil moisture in the warm growing season could negatively impact vegetation growth in the already dry area and could accelerate desertification unless the lost moisture can be replenished by increasing precipitation. In the northern NTP, the negative effects of top layer soil temperature increases on vegetation growth may also serve as an indication of the consequences of frozen soil degradation that is happening on the NTP (Cuo et al., 2015).

On the NTP, decreased (increased) vegetation growth in the northwest (southwest and northeast) will result in reduction (enhancement) in roughness length and increase (decrease) in albedo, changes in stomatal resistance, etc. These changes in biogeophysical properties over the region will feed back into the momentum and carbon exchange, water, and energy balances and will undoubtedly affect large scale circulations such as the onset and intensity of South Asia and East Asia monsoons (Wu et al., 2007; Shi and Liang, 2014; Cui et al., 2015; He et al., 2015), thereby affecting the regional and global climate.

In terms of the $\mathrm{CO}_{2}$ fertilization effect, Kimball (1983), Chang et al. (2016), Kim et al. (2016) and Schmid et al. (2016) stated that as $\mathrm{CO}_{2}$ level increased, vegetation yield changed, and the change was however related to the environment conditions such as light, soil nutrient and soil moisture and temperature. We assume that the $\mathrm{CO}_{2}$ fertilization effects can be reflected from the changes in photosynthesis and net primary productivity. In LPJ, photosynthesis calculation follows the method proposed by Farquhar et al. (1980) and Farquhar and von Caemmerer (1982) that was later modified by Collatz et al. (1991, 1992) and Haxeltine and Prentice (1996). The parameters that are used for photosynthesis calculation and PFT-specifics are temperature inhibition function limiting photosynthesis at low $\left(\mathrm{TLCO}_{2}\right)$ and high $\left(\mathrm{TUCO}_{2}\right)$ temperatures, and leaf phenology such as growing degree days to attain full leaf cover (GDDs). The values of these parameters are presented in Table 1. After carbon assimilation, net primary productivity is calculated by subtracting the maintenance respiration from gross primary productivity where leaf $\mathrm{C}: \mathrm{N}$ ratio, root $\mathrm{C}: \mathrm{N}$ ratio and sap $\mathrm{C}: \mathrm{N}$ ratio are used. These $\mathrm{C}: \mathrm{N}$ ratios are kept constant for all PFTs however. Based on photosynthesis and net primary productivity calculations and the PFT specific parameters used in the calculation, it can be inferred that individual PFTs have different responses to $\mathrm{CO} 2$ increase (see Table 6). As environmental conditions also affect the $\mathrm{CO}_{2}$ fertilization effects, $\mathrm{CO}_{2}$ increase does not necessarily result in the elevated net primary productivity as shown in Fig. $8 \mathrm{f}$ and Table 6 . Table 6 shows that different vegetation exhibits different responses to $\mathrm{CO}_{2}$ increase, among them PAMD displays primarily positive response to $\mathrm{CO}_{2}$ increase which also explains why PAMD has increased over a large portion of the study area during the past 52 years. Total FPC also shows positive response to the $\mathrm{CO}_{2}$ increase, which is mostly dominated by the positive PAMD response. Admittedly, the LPJ simulation may not reflect the reality because the model keeps $\mathrm{C}: \mathrm{N}$ ratios constant throughout the processes and the nitrogen effects on photosynthesis is simplified. This is certainly an area of further investigation and improvement.

To the authors' knowledge, this work is the first of its kind in that a state-of-the-art dynamic vegetation model is applied over the NTP for examining the impacts of both atmospheric conditions and soil physical conditions on plant coverages, and shows that atmospheric conditions dominate over the soil physical conditions in affecting the FPC change. This is highly relevant and timely given the fact that the Tibetan Plateau is experiencing warming and frozen soil degradation. Also, the output of time series vegetation type maps can be used in hydrological models to further investigate land cover change impacts on hydrological processes in the region where major Asian rivers are originated but where such long term time series land cover maps do not exist. Clearly, understanding the vegetation changes and the underlying mechanisms over the TP is the first step towards an understanding of the change impacts of TP's surface conditions on water resources, hydrological cycles and climate at regional and global scales. 
In this study, the role of $\mathrm{CO}_{2}$ in FPC changes is discussed solely in the context of photosynthesis. However, $\mathrm{CO}_{2}$ is a greenhouse gas and increasing $\mathrm{CO}_{2}$ concentrations have been credited as one of the primary driving forces behind the global warming. Without utilizing a fully coupled dynamic atmosphere-land surface-vegetation model it appears to be rather difficult to separate the effects of $\mathrm{CO}_{2}$ between photosynthesis related and greenhouse gas related.

\section{Conclusions}

In summary, this study documents the changes in PFTs represented by FPCs on the NTP during the past five decades and the possible mechanisms behind those changes through examining the responses of PFTs to changes in climate variables of precipitation, air temperature, atmospheric $\mathrm{CO}_{2}$ concentrations, $40 \mathrm{~cm}$-deep soil temperature and moisture. Among the five variables, precipitation is found to be the major factor influencing the total vegetation coverage positively, while root zone soil temperature is the least important one with negative impacts. About $34 \%$ of the NTP exhibits increasing total FPC trends compared to $13 \%$ with decreasing trends during 1957-2009. Individual PFTs respond differently to the changes in the five climate variables. The different responses of individual PFTs to climate change give rise to spatially varying patterns of vegetation change. Spatially diversified changes in vegetation coverage on the NTP are the result of changes in heterogeneous climatic conditions in the region, competitions among various PFTs for energy and water, and regional climate-determined bioclimatic restrictions for the establishment of different PFTs. The effects of the climate change induced regional plant functional type changes on water resources and hydrological cycles in one of the world's largest and most important headwater regions, on the partition of sensible and latent heat fluxes, and hence on the onset and intensity of south and east Asian monsoon circulations should be examined further.

\section{Data availability}

The data sets used in the study include LPJ model meteorological forcing, and the model output. Meterological forcings temperature and precipitation are available at http://www.tpedatabase.cn/portal/MetaDataInfo.jsp? MetaDataId=249432. Model output data are available through contact with Lan Cuo at lancuo@itpcas.ac.cn.

Author contributions. Lan Cuo designed the study, conducted the study and prepared the manuscripts. Yongxin Zhang provided critical suggestions in the study design and prepared the manuscripts. Shilong Piao helped with the manuscripts. Yanhong Gao provided suggestions in the study design.
Acknowledgements. This study is supported by the National Basic Research Program (grant 2013CB956004), by the National Natural Science Foundation of China (grant 41190083), and by the Hundred Talent Program granted to Lan Cuo by the Chinese Academy of Sciences. The National Center for Atmospheric Research (NCAR)'s Advanced Study Program (ASP) is also acknowledged for providing partial funding for this work.

Edited by: T. Keenan

\section{References}

Ahlstrom, A., Xia, J., Arneth, A., Luo, Y., and Smith, B.: Importance of vegetation dynamics for future terrestrial carbon cycling, Environ. Res. Lett., 10, 054019, doi:10.1088/17489326/10/5/054019, 2015.

Bonan, G. B., Pollard, D., and Thompson, S. L.: Effects of boreal forest vegetation on global climate, Nature, 359, 716-718, 1992.

Bonan, G., Levis, S., Sitch, S., Vertenstein, M., and Oleson K. W.: A dynamic global vegetation model for use with climate models: concepts and description of simulated vegetation dynamics, Glob. Change Biol., 9, 1543-1566, 2003.

Ciais, P., Schelhaas, M. J., Zaehle, S., Piao, S. L., Cescatti, A., Liski, J., Luyssaert, S., LeMaire, G., Schulze, E. D., Bouriaud, O., Freibauer A., Valentini, R., and Nabuurs, G. J.: Carbon accumulation in European forests, Nat. Geosci., 1, 425-429, 2008.

Chang, J., Ciais, P., Viovy, N., Vuichard, N., Herrero, M., Havlik, P., Wang, X., Sultan, B., and Soussana, J-F.: Effect of climate change, $\mathrm{CO}_{2}$ trends, nitrogen addition, and land-cover and management intensity changes on the carbon balance of European grasslands, Glob. Change Biol., 22, 338-350, 2016.

Chen, Z. Q., Shao, Q. Q., Liu, J. Y., and Wang, J. B.: Analysis of net primary productivity of terrestrial vegetation on the QinghaiTibet Plateau, based on MODIS remote sensing data, Science China: Earth Sciences, 55, 1306-1312, 2012.

Cheng, G. and Jin, H.: Permafrost and groundwater on the QinghaiTibet Plateau and in northeast China, Hydrogeol. J., 21, 5-23, 2013.

Chinese Academy of Sciences (CAS), 1:1000 000 China Vegetation Map, China Science Publishing \& Media Ltd, 2001.

Collatz G. J., Ball, J. T., Grivet C., and Berry J. A.: Physiological and environmental-regulation of stomatal conductance, photosynthesis and transpiration - a model that includes a laminar boundary-layer, Agr. Forest Meteorol., 54, 107-136, 1991.

Collatz, G. J., Ribas-Carbo, M., and Berry J. A.: Coupled photosynthesis-stomatal conductance model for leaves of C4 plants, Aust. J. Plant Physiol., 19, 519-538, 1992.

Cox, P. M.: Description of the TRIFFID dynamic global vegetation model, Hadley Centre Technical Note, 24, 1-16, 2001.

Cui, Y., Duan,A., Liu, Y., and Wu, G.: Interannual variability of the spring atmospheric heat source over the Tibetan Plateau forced by the North Atlantic SSTA, Clim. Dynam., 45, 1617-1634, 2015.

Cuo, L.: Land use/cover change impacts on hydrology in large river basins: a review, in: Terrestrial Water Cycle and Climate Change: Natural and Human-Induced Impacts, edited by: Tang, Q. and Oki, T., American Geophysical Union (AGU) Geophysical Monograph Series, accepted, 2016. 
Cuo, L., Lettenmaier, D. P., Alberti, M., and Richey, J.: Effects of a century of land cover and climate change on hydrology in Puget Sound, Washington, Hydrol. Process., 23. 907-933, 2009.

Cuo, L., Zhang, L., Gao, Y., Hao, Z., and Cairang, L.: The impacts of climate change and land cover transition on the hydrology in the Upper Yellow River basin, China, J. Hydrol., 502, 37-52, 2013a.

Cuo, L., Zhang, Y., Wang, Q., Zhang, L., Zhou, B., Hao, Z., and Su, F.: Climate change on the northern Tibetan Plateau during 19572009: spatial patterns and possible mechanisms, J. Climate, 26, 85-109, 2013b.

Cuo, L., Zhang, Y., Zhu, F., and Liang, L.: Characteristics and changes of streamflow on the Tibetan Plateau: A review, Journal of Hydrology: Regional Studies, 2, 49-68, 2014.

Cuo, L., Zhang, Y., Bohn, T.J., Zhao, L., Li, J., Liu, Q., and Zhou, B. Frozen soil degradation and its effects on surface hydrology in the northern Tibetan Plateau, J. Geophys. Res.-Atmos., 120, 8276-8298, 2015.

Dahlin, K. M., Fisher, R. A., and Lawrence, P. J.: Environmental drivers of drought deciduous phenology in the Community Land Model, Biogeosciences, 12, 5061-5074, doi:10.5194/bg12-5061-2015, 2015.

Elsner, M. M., Cuo, L., Voisin, N., Deems, J. S., Hamlet, A. F., Vano, J. A., Mickelson K. E. B., Lee S.-Y., and Lettenmaier, D. P.: Implications of 21st century climate change for the hydrology of Washington State, Climatic Change, 102, 225-260, 2010.

FAO: IIASA/ISRIC/ISS-CAS/JRC, Harmonized World Soil Database (version 1.0), FAO, Rome, Italy and IIASA, Laxenburg, Austria, 2008.

Farquhar, G. D., von Caemmerer, S., and Berry, J. A.: Abiochemical model of photosynthetic $\mathrm{CO}_{2}$ assimilation in leaves of $\mathrm{C}_{3}$ species, Planta, 149, 78-90, 1980.

Farquhar, G. D. and von Caemmerer, S.: Modelling of photosynthetic response to environmental conditions, in: Physiological plant ecology II: water relations and carbon assimilation, edited by: Nobel, P. S., Osmond, C. B., and Ziegler, H., Springer, Berlin, 549-587, 1982.

Fisher, R. A., Muszala, S., Verteinstein, M., Lawrence, P., Xu, C., McDowell, N. G., Knox, R. G., Koven, C., Holm, J., Rogers, B. M., Spessa, A., Lawrence, D., and Bonan, G.: Taking off the training wheels: the properties of a dynamic vegetation model without climate envelopes, CLM4.5(ED), Geosci. Model Dev., 8, 3593-3619, doi:10.5194/gmd-8-3593-2015, 2015.

Gerten, D., Schaphoff, S., Haberlandt, U., Lucht, W., and Sitch, S.: Terrestrial vegetation and water balance-hydrological evaluation of dynamic global vegetation model, J. Hydrol., 286, 249-270, 2004.

Haxeltine, A. and Prentice, I. C.: A general model for the lightuse efficiency of primary production, Funct. Ecol., 10, 551-561, 1996.

He, B., Wu, G., Liu, Y., and Bao, Q.: Astronomical and hydrological perspective of mountain impacts on the Asian summer monsoon, Sci. Rep., 5, 17586, doi:10.1038/srep17586, 2015.

Hopcroft, P. O. and Valdes, P. J.: Last glacial maximum constraints on the earth system model HadGEM2-ES, Clim. Dynam., 45, 1657-1672, 2015.

Huber, A., and Iroume, A.: Variability of annual rainfall partitions for different sites and forest covers in Chile, J. Hydrol., 248, 7892, 2001.
Jiang, Y., Zhuang, Q., Schaphoff, S., Sitch, S., Sokolov, A., Kicklighter, D., and Melillo, J.: Uncertainty analysis of vegetation distribution in the northern high latitudes during the 21st century wit a dynamic vegetation model, Ecol. Evol., 2, 593-614, 2012.

Jin, Z., Zhuang, Q., He, J., Luo, T., and Shi, Y.: Phenology shift from 1989 to 2008 on the Tibetan Plateau: an analysis with a process-based soil physical model and remote sensing data, Climatic Change, 119, 435-449, 2013.

Kim, D., Oren, R., and Qian, S. S.: Response to $\mathrm{CO}_{2}$ enrichment of understory vegetation in the shade of forests, Glob. Change Biol., 22, 944-956, 2016.

Kimball, B. A: Carbon dioxide and agricultural yield: an assemblage and analysis of 430 prior observations, Agr. J., 75,779-788, 1983.

Levis, S., Bonan, G. B., Vertenstein, M., and Oleson, K. W.: The community land model's dynamic global vegetation model (CLM-DGVM): technical description and user's guide., NCAR Techic Note, 459, 1-50, 2004.

Liang, X., Lettenmaier, D. P., and Wood, E. F.: A simple hydrologically based model of land surface water and energy fluxes for general circulation models, J. Geophys. Res., 99, 14415-14428, 1994.

Liang, X., Wood, E. F., and Lettenmaier, D. P.: Surface soil moisture parameterization of the VIC-2l model: evaluation and modification, Global Planet. Change, 13, 195-206, 1996.

Meng, T.-T., Wang, H., Harrison, S. P., Prentice, I. C., Ni, J., and Wang, G.: Responses of leaf traits to climatic gradients: adaptive variation versus compositional shifts, Biogeosciences, 12, 53395352, doi:10.5194/bg-12-5339-2015, 2015.

Mengis, N., Keller, D. P., Eby, M., and Oschlies, A.: Uncertainty in the response of transpiration to $\mathrm{CO}_{2}$ and implications for climate change, Environ. Res. Lett., 10, 94001-94001, 2015.

Mitchell, T. D. and Jones, P. D.: An improved method of constructing a database of monthly climate observations and associated high-resolution grids, Int. J. Climatol., 25, 693-712, 2005.

Murray, S. J.: Trends in 20th century global rainfall interception as simulated by a dynamic global vegetation model: implications for global water resources, Ecohydrology, 7, 102-114, 2014.

Paschalis, A., Fatichi, S., Katul, G. G., and Ivanov, V. Y.: Crossscale impact of climate temporal variability on ecosystem water and carbon fluxes, J. Geophys. Res.-Biogeo., 120, 1716-1740, 2015.

Pearson, R. G., Phillips, S. J., Loranty, M. M., Beck, P. S. A., Damoulas, T., Knight, S. J., and Goetz, S. J.: Shifts in Arctic vegetation and associated feedbacks under climate change, Nature Climate Change, 3, 673-677, doi:10.1038/nclimate1858, 2013.

Peterman, W., Bachelet, D., Ferschweiler, K., and Sheehan, T.: Soil depth affects simulated carbon and water in the MC2 dynamic global vegetation model, Ecol. Modell., 294, 84-93, 2015.

Piao, S., Tan, K., Nan, H., Ciais, P., Fang, J., Wang, T., Vuichard, $\mathrm{N}$., and Zhu, B.: Impacts of climate and $\mathrm{CO}_{2}$ changes on the vegetation growth and carbon balance of Qinghai-Tibetan grasslands over the past five decades, Global Planet. Change, 98-99, 73-80, 2012.

Qiu, J.: China: The third pole, Nature, 454, 393-396, 2008.

Reiter, E. R. and Gao, D. Y.: Heating of the Tibet Plateau and movements of the South Asian high during spring, Mon. Weather Rev., 110, 1694-1711, 1982. 
Rogers, B. M., Randerson, J. T., and Bonan, G. B.: Highlatitude cooling associated with landscape changes from North American boreal forest fires, Biogeosciences, 10, 699-718, doi:10.5194/bg-10-699-2013, 2013.

Sankarasubramanian, A., Vogel R. M., and Limbrunner J. F.: Climate elasticity of streamflow in the United States, Water Resour. Res., 37, 1771-1781, 2001.

Sato, H., Itoh, A., and Kohyama, T.: SEIB-DGVM: A new Dynamic Global Vegetation Model using a spatially explicit individualbased approach, Ecol. Modell., 200, 279-307, 2007.

Schmid, I., Franzaring, J., Muller, M., Brohon, N., Calvo, O. C., Hogy, P., and Fangmerier, H.: Effects of $\mathrm{CO}_{2}$ enrichment and drought on photosynthesis, growth and yield of and old and a modern barley cultivar, J. Agr. Crop Sci., 202, 81-95, 2016.

Shi, Q. and Liang, S.: Surface-sensible and latent heat fluxes over the Tibetan Plateau from ground measurements, reanalysis, and satellite data, Atmos. Chem. Phys., 14, 5659-5677, doi:10.5194/acp-14-5659-2014, 2014.

Sitch, S., Smith, B., Prentice, I. C., Arneth, A., Bondeau, A., Cramer, W., Kaplan, J. O., Levis, S., Lucht, W., Sykes, M. T., Thonicke, K., and Venevsky, S.: Evaluation of ecosystem dynamics, plant geography and terrestrial carbon cycling in the LPJ dynamic global vegetation model, Glob. Change Biol., 9, 161-185, 2003.

Sitch, S., Brovkin, V., Von Bloh, W., Van Vuuren, D., and Eickhout, B.: Impacts of future land cover changes on atmospheric $\mathrm{CO}_{2}$ and climate, Global Biogeochem. Cy., 19, GB2013, doi:10.1029/2004GB002311, 2005.

Sitch, S., Huntingford, C., Gedney, N., Levy, P. E., Lomas, M., Piao, S. L., Betts, R., Ciais, P., Cox, P., Friedlingstein, P., Jones, C. D., Prentice, I. C., and Woodward, F. I.: Evaluation of the terrestrial carbon cycle, future plant geography and climate-carbon cycle feedbacks using five Dynamic Global Vegetation Models (DGVMs), Glob. Change Biol., 14, 2015-2039, 2008.

Sitch, S., Friedlingstein, P., Gruber, N., Jones, S. D., MurrayTortarolo, G., Ahlström, A., Doney, S. C., Graven, H., Heinze, C., Huntingford, C., Levis, S., Levy, P. E., Lomas, M., Poulter, B., Viovy, N., Zaehle, S., Zeng, N., Arneth, A., Bonan, G., Bopp, L., Canadell, J. G., Chevallier, F., Ciais, P., Ellis, R., Gloor, M., Peylin, P., Piao, S. L., Le Quéré, C., Smith, B., Zhu, Z., and Myneni, R.: Recent trends and drivers of regional sources and sinks of carbon dioxide, Biogeosciences, 12, 653679, doi:10.5194/bg-12-653-2015, 2015.

Smith, B., Prentice, I. C., and Sykes, M. T.: Representation of vegetation dynamics in the modeling of terrestrial ecosystems: comparing two contrasting approaches within European climate space, Global Ecol. Biogeogr., 10, 621-637, 2001.

Smithwick, E. A. H., Ryan, M. G., Kashian, D. M., Romme, W. H., Tinker, D. B., and Turner, M. G.: Modeling the effects of fire and climate change on carbon and nitrogen storage in lodgepole pine (Pinus contorta) stands, Glob. Change Biol., 15, 535-548, 2009.
Steinkamp, J. and Hickler, T.: Is drought-induced forest dieback globally increasing?, J. Ecol., 103, 31-43, 2015.

Swank, W. T. and Douglass, J. E.: Streamflow greatly reduced by converting deciduous hardwood stands to pine, Science, 185, 857-859, 1974.

Tatarinov, F. A. and Cienciala, R.: Application of BIOME-BGC model manage forests 1: sensitivity analysis, Forest Ecol. Manage., 237, 267-279, 2006.

Wang, B., Bao, Q., Hoskins, B., Wu, G., and Liu, Y.: Tibetan Plateau warming and precipitation changes in East Asia, Geophys. Res. Lett., 35, L14702, doi:10.1029/2008GL034330, 2008.

Wang, X., Cheng, G., and Zhong, X.: Assessing potential impacts of climatic change on subalpine forests on the eastern Tibetan Plateau, Climatic Change, 108, 225-241, 2011.

Weiss, M., Miller, P. A., van den Hurk, B. J. J. M., van Noije T., Tefanescu, S. S., Haarsma, R., van Ulft, L. H., Hazeleger, W., Le Sager, P., Smith, B., and Schurgers, G.: Contribution of dynamic vegetation phenology to decadal climate predictability, J. Climate, 27, 8563-8577, 2014.

Wigmosta, M.S., Vail, L. W., and Lettenmaier, D. P.: A distributed hydrology vegetation model for complex terrain, Water Resour. Res., 30, 1665-1679, 1994.

Wu, G. X., Liu, Y., Wang, T., Wan, R., Liu, X., Li, W., and Liang, X.: The influence of mechanical and thermal forcing by the Tibetan Plateau on Asian climate, J. Hydrometeorol., 8, 770-789, 2007.

Yanai, M., Li, C., and Song, Z.: Seasonal heating of the Tibetan Plateau and its effects on the evolution of the summer monsoon, J. Meteorol. Soc. Japan, 70, 319-351, 1992.

Ye, D. Z. and Wu, G. X.: The role of the heat source of the Tibetan Plateau in the general circulation, Meteorol. Atmos. Phys., 67, 181-198, 1998.

Yeh, T. C. and Gao, Y. X.: The Meteorology of the Qinghai-Xizang (Tibet) Plateau, edited by: Yeh, T.-C. and Gao, Y.-X., Science Press, Beijing, China, 278 pp., 1979 (in Chinese).

Zhang, Y., Li, T., and Wang, B.: Decadal change of the spring snow depth over the Tibetan Plateau: The associated circulation and influence on the East Asian summer monsoon, J. Climate, 17, 2780-2793, 2004.

Zhang, Y., Wang, X., Hu, R., Pan, Y., and Paradeloc, M.: Rainfall partitioning into throughfall, stemflow and interception loss by two xerophytic shrubs within a rain-fed re-vegetated desert ecosystem, northwest China, J. Hydrol., 527, 1084-1095, 2015.

Zheng, D., Yang, Q. Y., and Wu, S. H.: Eco-geographical Region System of China, Beijing: The Commercial Press, 2008 (in Chinese).

Zhong, L., Ma, Y., Suhyb, S. M., and Su, Z.: Assessment of vegetation dynamics and their response to variations in precipitation and temperature in the Tibetan Plateau, Climatic Change, 103, 519-535, 2010. 